\title{
Decarbonizing International Air Cargo Transportation's Carbon Footprint: A Review of the World Air Cargo Carrying Airlines Current and Potential Environment Related Measures and Strategies
}

\author{
Glenn Baxter
}

School of Tourism and Hospitality Management, Suan Dusit University, Huahin Prachaup Khiri Khan, Thailand, 77110.

Received: 27 Oct 2021; Received in revised form: 07 Dec 2021; Accepted: 15 Dec 2021; Available online: 23 Dec 2021 (c)2021 The Author(s). Published by Infogain Publication. This is an open access article under the CC BY license (https://creativecommons.org/licenses/by/4.0/).

\begin{abstract}
Using an in-depth instrumental case study research design, this study has examined the current environmental related measures and strategies that have been defined and implemented to decarbonize air cargo operations by the world's air cargo carrying airlines. The study covered the period 2004 to 2021. The case study found that the world's air cargo carrying airlines are very cognizant of their environmental impact and, as a result, these airlines have defined and implemented an extensive range of measures and strategies to decarbonize their operations. These measures include the acquisition and deployment of fuel-efficient next generation aircraft, aircraft related carbon dioxide $\left(\mathrm{CO}_{2}\right)$ emissions offset programs, the use of fixed electrical ground power (FEGP) and pre-conditioned air at airports, the use of lightweight aircraft unit load devices (ULDs), use of sustainable aviation fuels, the use of renewable energy sources for ground based buildings and facilities, the electrification of air cargo carrying airlines ground service equipment (GSE), the optimization of air traffic management procedures, and the washing of aircraft engines. A key strategy adopted by the world's air cargo carrying airlines has been the use of sustainable aviation fuels (SAF), as this fuel source provides a very significant opportunity for the decarbonization of aircraft operations. Several key air cargo industry actors are planning in the future to use electric powered aircraft. Hydrogen as an aircraft energy source is also being considered. To mitigate the environmental impact of wastes, air cargo carrying airlines could consider adopting the circular economy waste management approach.
\end{abstract}

Keywords - Air cargo carrying airlines, Air cargo carrying airlines decarbonization measures, Case study, Decarbonization, Sustainable aviation fuels.

\section{INTRODUCTION}

Due to the adverse impact on the environment, the biggest issue confronting the global air transport industry today is sustainability (Turner, 2021g). Indeed, sustainability has assumed strategic importance in the air transport industry (Graham, 2021b). Consequently, all around the world, the environmental sustainability of air transport has been receiving greater focus in recent times due to its critical impact on climate change and on the environment (Budd, 2017; Chen, 2012; Teoh \& Khoo, 2016). Environmental issues associated with the global air transport industry have grown in importance in recent years, and in response airlines have been proactive by demonstrating their "green" credentials (Mayer et al., 2012; Migdadi, 2018). In recent decades, greening (ensuring the sustainable development of the global air transport system) has been viewed as a highly significant part of the agenda by almost all the industry's involved stakeholders (Janić, 2011). These stakeholders include aviation organizations for international cooperation; international aviation organizations; air transport system operators, for example, airports, air traffic control (ATC) and airlines; aerospace manufacturers; non- 
governmental organizations; users, for example, passengers and air cargo shippers; and research, scientific and consultancy organizations (Janić, 2016). The aim of a "green airline" is to provide the green society with a transport system that reduces its carbon footprint, uses renewable energy, and produces less carbon dioxide $\left(\mathrm{CO}_{2}\right)$ emissions as well as other harmful pollutants (Abdullah et al., 2016). The concept of "greening" aviation firms, such as, airlines, can be best linked to their reduction of the level of emissions into the atmosphere, to the point where these airlines achieve near carbon neutrality (Sarkar, 2012).

The air transportation of goods/freight for commercial purposes plays a very significant role in the world economy (Alemán, 2010; Dewulf et al., 2019; Heng, 2016). Air cargo is defined as "anything carried in an aircraft except for mail or luggage carried under a passenger ticket and baggage check but including baggage shipped under an airway bill or shipment record" (Hui et al., 2004). Passenger baggage is associated with the carriage of passengers and is included as part of the individual passenger's air fare. Passenger baggage is therefore not a part of the air cargo service. (Dempsey \& Gesell, 1997). Air cargo consignments are typically time sensitive and/or are high value-to-weight goods (Budd \& Ison, 2017). The five key industry sectors that utilize the air cargo mode are equipment, consumer electronics, pharmaceuticals, healthcare, and retail products sectors. When combined they comprise around $90 \%$ of total world air cargo traffic. In addition, the air cargo mode is used by firms from varying market sectors and geographic region's locations to connect them to new customers and suppliers that may not be otherwise accessible by other transport modes (Turner, 2021f).

In the world air cargo industry, air cargo capacity is provided by three distinct types of airline operators. Combination passenger airlines are airlines that carry passengers on the main deck and transport air cargo in their passenger aircraft lower lobe belly-holds. Some combination airlines, for example, Cathay Pacific Airways, Qatar Airways, and Singapore Airlines, also operate freighter aircraft. Shippers may also decide to use dedicated all-cargo airlines, for example, Cargolux International Airlines or Nippon Cargo Airlines (NCA). The final type of air cargo carrying airline operator is the integrated carriers, for example, DHL Express, FedEx and United Parcel Service (UPS) (Baxter \& Wild, 2021; Dresner \& Zou, 2017; Merkert \& Alexander, 2019). The integrated carriers operate very large fleets of freighter aircraft. A freighter aircraft is an aircraft that has been expressly designed or which has been converted to transport air cargo, express, and so forth, rather than passengers (Wensveen, 2016). All-cargo services are operated with freighter aircraft where all the available capacity is dedicated to air cargo transportation (Dresner \& Zou, 2017; Tretheway \& Andriulaitis, 2016). Dedicated all-cargo services are vital to the aviation industry, and to the global economy (Davies, 2013). Around 56 per cent of global air cargo revenue ton kilometres (RTKs) is carried in dedicated freighter aircraft (Boeing Commercial Airplanes, 2020). In providing air cargo services, airlines have various environmental impacts (Sales, 2013, 2016, 2017). These environmental impacts include the production of greenhouse gas (GHG) emissions both in-flight and from ground operations, the production of large volumes of waste, and the consumption of significant amounts of resources, such as, jet fuel, energy for ground-based facilities and ground handling equipment, and water.

Both climate change and carbon footprints are now frequently being regarded as two of the most urgent concerns confronting society and are now viewed as key issues of corporate responsibility (Hrasky, 2012). According to Wiedemann and $\operatorname{Minx}$ (2007, p. 5), "the carbon footprint is a measure of the exclusive total amount of carbon dioxide emissions that is directly and indirectly caused by an activity or is accumulated over the life stages of a product". Carbon footprints are now being extensively used as a measure of an organization's contribution to climate change (De Grosbois \& Fennell, 2011). The measurement of its carbon footprint enables firms to estimate their own contributions to the changing climate (Gautam et al., 2012). Carbon foot printing is now one of the principal methods available to firms for quantifying their anthropogenic environmental impacts and for assisting them to tackle the threat of climate change (Williams et al., 2012).

The objective of this study is to examine the current environmental related measures and strategies that have been defined and implemented to decarbonize air cargo operations by the world's air cargo carrying airlines. The first objective is to identify the various environmental impacts that air cargo carrying airlines will have on the natural environment. The second objective is to identify and examine the various environmental related measures and strategies that have been implemented by air cargo carrying airlines, irrespective of their chosen business model, to decarbonize their air cargo operations. A further objective is to examine the benefits for air cargo carrying airlines of implementing sustainable waste management practices. This is because the disposal of wastes can also be a source of carbon dioxide $\left(\mathrm{CO}_{2}\right)$ emissions, especially if the wastes are disposed to landfill. The levels of emissions from waste are dependent upon how the waste is treated (Eurostat, 2020). The study covered the period 2004 to 2021. 'Decarbonization' often refers to the process of 
reducing 'carbon intensity'. This is achieved by a firm lowering the amount of greenhouse (GHG) gas emissions that is produced from the burning of fossil fuels (TWI Ltd, 2021).

The remainder of the paper is organized as follows: The literature review is presented in Section 2. Section 3 describes the study's research methodology that underpinned the study. The case study is presented in Section 4. Section 5 outlines the study's conclusions.

\section{BACKGROUND}

\subsection{A Brief Overview of the Global Air Cargo Industry}

Historically, the world air cargo industry has been a high growth industry (Albers, 2015). This trend can be observed in Figure 1 which shows the growth in total annual world domestic/international enplaned air cargo tonnage and freight tonne kilometres performed (FTKs) from 2000 to 2019. Over this period, the total annual enplaned tonnage and FTKs grew from 30 million tonnes and 118.0 billion FTKs in 2000 to 57.6 million tons and 225 billion FTKs in 2019, respectively. Freight tonne kilometres performed (FTKs) are calculated from the multiplication of freight tonnes carried by the distance of the flight. Most domestic cargo is transported in the USA and is principally carried by the integrated carriers, such as FedEx and United Parcel Service (UPS) (Doganis, 2019). The air cargo industry is cyclical in nature (Doganis, 2019; Morrell \& Klein, 2018) and is sensitive to changes in any cyclical economic movements (Macário \& Van de Voorde, 2011). Figure 1 shows that total world air cargo traffic (domestic and international enplaned tonnage and FTKs) showed marked declines in 2001 and 2008 following the tragic events of September 11 and the 2008-2009 global financial crisis (GFC)

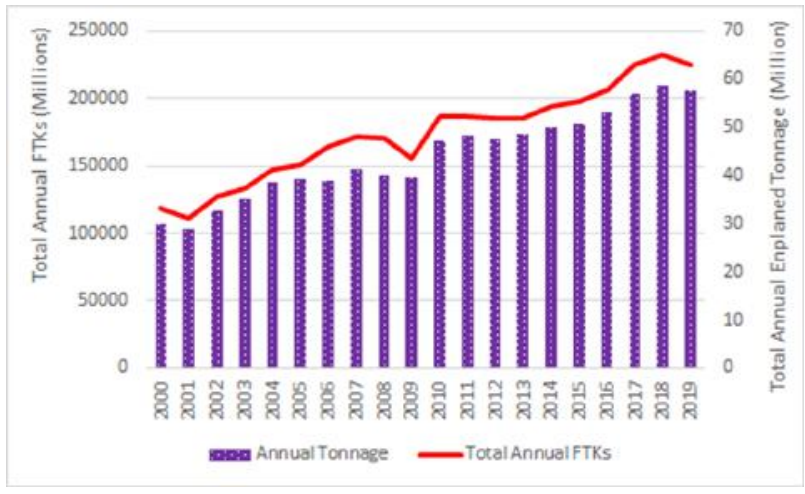

Fig.1: World air cargo industry total annual enplaned tonnage and freight tonne kilometres (FTKs) performed:

2000-2019. Source: International Civil Aviation

Organization (2012, 2013, 2020).
Air cargo service providers are a heterogeneous group of actors. Together they deliver various logistics and supply chain services as well as their expertise. The air cargo industry is comprised of various commercial firms that provide shippers and/or consignees with their desired air cargo services. An airline provides transportation for air cargo consignments from the airport of origin to the destination airport. Combination airlines include airlines that provide both passenger and air cargo services. Most international carriers fall into this category. Combination airlines generally provide customers with airport-to-airport services and these airlines rely on air freight forwarders to perform the remaining transport logistics and supply chain services. Dedicated all-cargo airlines operate scheduled freighter flights on routes where there is regular heavy air cargo demand or where the potential passenger traffic is not large. The all-cargo airlines normally carry air cargo only on an airport-to-airport basis. The all-cargo airlines also provide charter services. The integrators are firms that integrate the air and ground transport services traditionally performed by separate firms and they provide a full doorto-door service. The integrators also provide supply chain and logistics solutions, which are underpinned by highly advanced IT systems (Baxter \& Wild, 2021). International air freight forwarders are another very important actor in the global air cargo supply chain and these firms' contract with airlines for the physical carriage of goods. Freight forwarders often purchase block cargo space on airlines flights. Freight forwarders often work closely with complementary surface transportation service providers (Al Hajri, 1999).

\subsection{The Environmental Impact of Air Transport Operations}

\subsubsection{Aircraft emissions}

The growth of commercial air transport has driven concerns over air quality (Gössling \& Upham, 2009) as air traffic growth has increased the air transport industry's annual carbon dioxide $\left(\mathrm{CO}_{2}\right)$ emissions (Fatihah \& Abdul Rahim, 2017). The global aviation industry carbon dioxide $\left(\mathrm{CO}_{2}\right)$ emissions contribute to global warming (Chiambaretto et al., 2021). Thus, an environmental threat has emerged, that of aircraft emissions (Marais et al., 2016; Masiol \& Harrison, 2014; Wey \& Lee, 2017). By consuming fuel, aircraft produce emissions of carbon dioxide $\left(\mathrm{CO}_{2}\right)$, nitrogen oxides $\left(\mathrm{NO}_{\mathrm{X}}\right)$, particles (principally soot) of sulphur oxides, carbon monoxide (CO), as well as various hydrocarbons. First, and generating the largest percentage share, are the emissions of carbon dioxide $\left(\mathrm{CO}_{2}\right)$, which are produced in direct proportion to the volume of jet fuel used to operate flights over any distance (Sales, 2017). 
Aircraft operating at subsonic speeds in flight cause the following main effects to the environment:

- Carbon dioxide $\left(\mathrm{CO}_{2}\right)$ : carbon dioxide $\left(\mathrm{CO}_{2}\right)$ emissions are the most common (Sales, 2016). Carbon dioxide $\left(\mathrm{CO}_{2}\right)$ emissions are acknowledged as a major contributor to climate change (Abd et al., 2021; Yadhav \& Wang, 2017; Zhang et al., 2020).

- Oxides of nitrogen $\left(\mathrm{NO}_{\mathrm{x}}\right)$ : at high altitudes $\mathrm{NOx}$ emissions help to form ozone in the upper troposphere. They also reduce methane, which results in a cooling effect.

- Water vapor (H2O): Water vapor is created through the burning of jet fuel. At altitude, condensation trails form, consisting of frozen ice crystals that deflect a small amount of sunlight away from the Earth's surface and reflect more radiation back towards the Earth. This results in an overall warming effect on the Earth's atmosphere (Sales, 2016, p.146).

Pollutants are also produced during aircraft taxiing, at takeoff, at landing, and often during the period when aircraft are sitting idle. Surface vehicles associated with the transportation of crews and their baggage are another source of pollutants (Prosperi, 2009).

\subsubsection{Aircraft fuel efficiency}

Increasing environmental concerns have drawn significant attention of the air transport industry towards the requirement for judicious use of aviation fuel. Consequently, both economic and environmental sustainability concerns have led to dramatic progress in aviation fuel efficiency improvements in the past decades (Singh et al., 2018).

In recent times, both airlines and the aircraft manufacturers have invested in new technologies and strategies to reduce aircraft fuel consumption and the concomitant emissions. Aircraft fuel has a close relationship with the emissions of carbon dioxide $\left(\mathrm{CO}_{2}\right)$ and other gases that result in climate change (Zou et al., 2016).

\subsection{Carbon offsetting and reduction scheme for international aviation (CORSIA)}

The 2015 Paris Climate Conference or COP 21 agreement provided a stimulus for the air transport industry to develop a global market-based measure (MBM) to reduce carbon dioxide $\left(\mathrm{CO}_{2}\right)$ emissions (Singapore Airlines, 2017). Effective in 2021, an increased share of the carbon emission growth in the international air transport industry will be subject to offsetting under the International Civil Aviation Organization (ICAO) "Carbon Offsetting and Reduction Scheme for International Aviation” (CORSIA) program (Kováčik et al., 2021; Maertens et al., 2019). Effective from 1 January 2021, all international flights will become subject to offsetting obligations under the CORSIA program (International Air Transport Association, 2021b). The objective of the Carbon Offsetting and Reduction Scheme for International Aviation, or CORSIA program, is the stabilization of carbon dioxide $\left(\mathrm{CO}_{2}\right)$ emissions at 2020 levels. Consequently, this will require airlines to offset the growth of their emissions from 2020 onwards. Airlines will also be required to monitor emissions on all their international services as well as offsetting emissions from air routes included in the scheme through the purchase of eligible emission units that are generated by projects that reduce emissions in other sectors (for example renewable energy) (European Commission, 2021).

The CORSIA program will be implemented in three discrete phases with the pilot phase operating from 20212023. The first phase will be from 2024 to 2026. Both the pilot and first phases are voluntary. The second phase of the program is targeted at the 2027 to 2035 time-period (Javed et al., 2019). Following the completion of the pilot and first phases, a second mandatory scheme will enter in effect for all ICAO member states, except for some least developed countries (Scott \& Trimarchi, 2020). The global COVID-19 pandemic resulted in a very significant decline in the worldwide aviation industry traffic and, as a result, the International Civil Aviation Organization (ICAO) adjusted its CORSIA program by removing 2020 emissions from the baseline, which are now based on 2019 emission levels (Zhang et al., 2021). The voluntary pilot period for ICAO's CORSIA program became effective as of 2021 and will become mandatory for all airlines from 2027 onwards (Singapore Airlines, 2021).

\subsection{The Reduction in Aircraft Weights as an Environmental Mitigation Measure}

In recent times, airlines from around the world have implemented a range of measures that have been designed to lower the weight of their aircraft, and thus, reduce fuel burn and the associated harmful emissions. The weight saving initiatives include the correct stowage of items to avoid unnecessarily ordering catering supplies and other in-flight service equipment, the removal of rubbish, and the reduction in on-board company materials. In addition, airlines have implemented potable water strategies whereby they carefully optimize the water uplift on flights to satisfy passenger requirements whilst at the same time achieving fuel and emissions savings from the lower the aircraft weight (Baxter, 2016). 


\subsection{The Use of Sustainable Aviation Fuels as an Environmental Related Measure}

Alternative fuels can help industry stakeholders to provide sustainable air transport since these fuels reduce the air transport industry climate-relevant emissions (Scheelhaase et al., 2019). Considering this one of the most important trends in the global airline industry in recent times has been the uptake in the use of sustainable aviation biofuel. Airlines now regard the use of aviation biofuel as being a key environmental sustainability measure (Baxter et al., 2020; Bittner et al., 2015; Cortez et al., 2015). As a result, alternative jet fuel (AJF) technologies have gained considerable interest and are now regarded as a way for the industry to achieve large, near-term emissions reductions (Staples et al., 2014). Currently, sustainable aviation fuel (SAF) is a drop-in solution. This means that current aircraft can use a 50 percent blend of sustainable aviation fuel (SAF) and common Jet A fuel without any modifications (Reichmann, 2021a).

Air cargo is in a strong position to lead the air transport industry in the adoption of green initiatives, with sustainable aviation fuel (SAF) proving to be the best way for the industry to reduce its carbon dioxide $\left(\mathrm{CO}_{2}\right)$ emissions (Brett, 2021a). Sustainable jet fuels now underpin the airline industry's strategy to reduce their carbon emissions (Gegg et al., 2014; Schäfer, 2016). According to Tavares Kennedy (2019), “depending upon the raw material used in its production, biofuels can reduce carbon dioxide $\left(\mathrm{CO}_{2}\right)$ emissions by $60-80 \%$ ". The International Air Transport Association (2021a) have observed that sustainable aviation fuel can reduce emissions by up to $80 \%$ over its full lifecycle (International Air Transport Association, 2021a).

Aviation biofuels are therefore becoming an important substitute for fossil fuel in the airline industry. The use of aviation biofuels help with an airline's sustainability goals as they are environmentally friendly ( $\mathrm{Su}$ et al., 2015). Furthermore, the replacement of fossil fuels by sustainable aviation biofuels is one of the principal strategies adopted in the global airlines to decrease their carbon dioxide $\left(\mathrm{CO}_{2}\right)$ emissions by $50 \%$ by 2050 (Bauen \& Nattrass, 2018; Dodd et al., 2018). Hence, the airline industry now views the use of sustainable biofuels as being the key long-term technology for decarbonizing aviation (Fregnani \& Andrade, 2017). Furthermore, airlines are counting on sustainable aviation fuels (SAF) to reduce their carbon dioxide $\left(\mathrm{CO}_{2}\right)$ emissions in the years prior to electric and hydrogen-based propulsion systems become widely available, which will most likely occur after 2035 (Air Cargo World, 2021).

\section{RESEARCH METHODOLOGY}

\subsection{Research Approach}

The research undertaken in the present study used an instrumental case study research approach (Beasley \& Bernadowski, 2019; Honeycutt \& Miller, 2021; Sadang et al., 2021). An instrumental case study is the study of a case so that it provides insights into a specific issue, redraws generalizations, or builds theory (Stake, 1995, 2005). An instrumental case study is designed around established theory of the phenomenon under study (Grandy, 2010). The present study was designed around the established theory of airline carbon footprints (Tuladhar et al., 2021), carbon footprints (Franchetti \& Apul, 2013; Hunter, 2014; Ramachandra \& Mahapatra, 2016), sustainable aviation (Budd et al., 2013; Palmer, 2020; Ydersbond et al., 2020), sustainable aviation biofuels (Cortez, 2014; Gegg et al., 2014; Schäfer, 2016), and the environmental impact of air cargo operations (Sales, 2013, 2016, 2017).

\subsection{Data Collection}

The documents collected and examined in the study included news items in the leading air cargo industry related journals and magazines, airline annual sustainability reports, press releases, and airline's websites. A comprehensive search of the air transport and air cargo industry related magazines was also conducted. The SCOPUS and Google Scholar databases were also examined in the study.

The study followed the three principles of data collection as recommended by Yin (2018), that is, the use of multiple sources of case evidence, creation of a database on the subject, and the establishment of a chain of evidence.

\subsection{Data Analysis}

The data collected for the case study was examined using document analysis. Document analysis focuses on the information and data that is obtained from the formal documents and company records gathered by the researcher(s) (Oates, 2006; Ramon Gil-Garcia, 2012; Yin, 2018). In this study, the documents were examined for their authenticity, credibility, representativeness, and meaning (Scott, 2014; Scott \& Marshall, 2009).

The key words used in the database searches included "air cargo carrying airlines decarbonization strategies and measures", "air cargo carrying airlines acquisition and deployment of fuel-efficient next generation aircraft", "air cargo carrying airlines offsetting of aircraft related carbon dioxide $\left(\mathrm{CO}_{2}\right)$ emissions", "air cargo carrying airlines use of electric powered aircraft", " air cargo carrying airlines use of fixed electrical ground power at airports", "air cargo carrying airlines potential use of hydrogen as an aircraft energy source", "air carrying airlines use of lightweight 
aircraft unit load devices", "air cargo carrying airlines use of sustainable aviation fuels as an industry decarbonization related measure", "air cargo carrying airlines use of renewable energy sources for ground based buildings and facilities", "air cargo carrying airlines use of sustainable waste management principles", "electrification of air cargo carrying airlines ground service equipment (GSE)", the "Sustainable Air Freight Alliance", "the optimization of air traffic management procedures", and the "washing of aircraft engines by air cargo carrying airlines".

The study's document analysis was conducted in six distinct stages. The first stage involved planning the types and required documentation and ascertaining their availability for the study. In the second phase, the data collection involved sourcing the documents that were necessary to conduct the study. This stage of the document analysis process also involved the development and implementation of a scheme for managing the documents collected for the study. The documents were carefully examined to assess their authenticity, credibility and to identify any potential bias in the third stage of the document analysis process. In the fourth stage, the content of the collected documents was carefully examined, and the key themes and issues were identified and recorded. The fifth stage involved the deliberation and refinement to identify any difficulties associated with the documents, reviewing sources, as well as exploring the documents content. In the sixth and concluding stage, the analysis of the data was finalized (O'Leary, 2004).

Following the guidance of Yin (2018), the study's documents were stored in a case study database. All the documents collected for the study were in English. Each document was carefully read, and key themes were coded and recorded in the case study (Baxter, 2020).

\section{RESULTS}

\subsection{The Acquisition and Deployment of Fuel-Efficient Next Generation Aircraft}

A key strategy adopted by the combination airlines, allcargo airlines, and the integrated carriers in recent times has been the renewal of their aircraft fleets with more fuel efficient, and thus, lower-emissions aircraft. Over the past decade, next generation twin engine, long-haul aircraft have entered commercial service (Aircraft Commerce, 2016). The Airbus A350 XWB family was initially intended to have three variants: the Airbus A350-800, Airbus A350-900, and the Airbus A350-1000. The Boeing 787 Dreamliner family includes the 787-8, 787-9, and the 787-10. The Airbus A350-900XWB entered commercial service with Qatar Airways in 2014 (Aircraft Commerce, 2015). The first Airbus A350-1000 was delivered to Qatar
Airways in February 2018 (Airbus, 2018). The Boeing 787-8 entered commercial service in 2011, whilst the 787-9 began commercial services in 2014 with Japan-based All Nippon Airways (Aircraft Commerce, 2015). Singapore Airlines took delivery of the first Boeing 787-10 on March 14th, 2018 (Boon, 2020). The Airbus A350 and Boeing 787 aircraft families are more fuel efficient (Salvatore, 2020). Airlines changing aircraft from the Boeing 767 and Airbus A340 to the newer Airbus A350, and Boeing 787 can reduce their aircraft emissions by $15-20 \%$ when flying on the same route (Szymczak, 2021). Thus, airlines operating Airbus A350 and Boeing 787 aircraft can reduce their carbon footprint. Furthermore, airlines have recently introduced new single-aisle aircraft (for example, the Airbus A220-100 and -300) and several derivative aircraft which have major propulsion and airframe technology upgrades (for example, the Airbus A320neo and A330neo, and the Boeing B737 MAX family). These new aircraft models have commenced commercial airline service in recent times and these aircraft provide substantial reductions in aircraft fuel burn (International Coordinating Council of Aerospace Industries Associations, 2019), and the concomitant aircraft emissions.

The 747-8 Intercontinental (the passenger variant of the Boeing 747-8 aircraft) improves fuel efficiency by $16 \%$ as compared to its predecessor the Boeing 747-400, Since introduction into commercial service in 2011, the Boeing 747-8's fuel efficiency has been further improved by an additional 3.5\%. (Air Transport Action Group, 2021a)

As noted earlier, around half of world cargo traffic is carried in the lower lobe belly hold compartments of passenger aircraft with the remainder transported on dedicated freighter aircraft (Morrell, 2016). Since the late 2000s, the aircraft manufacturers, Airbus and Boeing Commercial Airplanes, have enhanced their freighter aircraft range and the improvement in new technologies has resulted in greater fuel efficiency, and thus, lower aircraft emissions. Small standard size and medium size freighter aircraft are operated by airlines because of their capability to operate high-frequency services. In recent times passenger to freighter $(\mathrm{P} 2 \mathrm{~F})$ have assumed a key role in the global air cargo industry. The Airbus A321P2F, Boeing B737P2F, Boeing B737-400P2F, and Boeing 737800P2F passenger aircraft have largely replaced the older Boeing B727 and McDonnell Douglas DC9F aircraft, with several companies offering Airbus A321 and Boeing B737 passenger-to-freighter $(\mathrm{P} 2 \mathrm{~F})$ aircraft conversion services. Medium-capacity wide-body freighter aircraft such as the Airbus A330-200F and Boeing B767-300F, are operated extensively by the integrated carriers and by some nonintegrated carriers. 
The Airbus A330-200F was launched in January 2007, with commitments from Indian cargo start-up Flyington Freighters and lessor companies Intrepid Aviation Group and Guggenheim Aviation Partners for 32 aircraft (Kingsley-Jones, 2010). The A330-200F is a derivative of the very popular Airbus A330 Family. The A330-200F aircraft benefits from full operational commonality unique to Airbus due to the Airbus Fly-By-Wire technology which also enables faster pilot transitioning to and from other Airbus aircraft, both passenger and freighter aircraft. The Airbus A330-200 freighter is a mid-size, long-haul dedicated all-cargo aircraft. When operating in payload mode the aircraft can carry a 70 metric tons structural payload over a range of 4074.4 kilometres $(2,200 \mathrm{~nm})$. In range mode, the aircraft can carry a 65 metric tons payload (Ierovante et al., 2015) over a range of $7,400 \mathrm{~km}(4,000 \mathrm{~nm})$ (Kingsley-Jones, 2006).

Derived from the popular Boeing 767-300ER (extended range) passenger twinjet, the Boeing B767-300F benefits from the advanced avionics, aerodynamics, materials, and propulsion incorporated on Boeing 767 passenger aircraft. The Boeing B767-300 freighter aircraft can carry a payload of 52.5 tonnes over a range of 3,255 nautical miles/ 6,028 kilometres (Boeing Commercial Airplanes, 2021). Importantly, the Boeing B767-300 freighter aircraft is more fuel efficient than other aircraft offered in the medium sized freighter aircraft market segment (Boeing Commercial Airplanes, 2014)

Aimed at the large freighter market and launched in May 2005 on the back of the newly available Boeing 777200LR airframe/engine combination, the Boeing 777200LRF freighter aircraft offers a 103.9 tonne revenue payload capability (Norris 2006). The economics of the aircraft are extremely favourable with cargo density identical to the Boeing B747-400F (Conway, 2005), and 20 per cent lower fuel burn than the Boeing B747-400F, and thus, this aircraft has lower emissions levels. The Boeing 777 freighter aircraft can carry its full cargo load over a range of 9,000 kilometres (Ostrower, 2008). The Boeing B777-200LRF freighter entered service with Air France in 2009 (Conway, 2011).

The new-technology Boeing 747-8 Freighter was the latest version of the Boeing B747 freighter aircraft family. Boeing launched the 747-8 Family with orders for the freighter aircraft in November 2005 from Cargolux and Nippon Cargo Airlines (NCA), after considerable study of the market feasibility of a new 747 (Conway, 2012). By working together with customers and applying innovative new technologies from the 787 Dreamliner aircraft, Boeing was able to develop and offer the 747-8 freighter aircraft to airlines competing in the large aircraft size global air cargo market segment. The maximum payload of Boeing's next generation B747-8F is around 134 tonnes (Conway, 2005). The freighter aircraft has a range of $8,130 \mathrm{~km}$ and has a $16 \%$ higher cargo volume than the 747-400. The Boeing $747-8$ Freighter has a range of 4,475 nautical miles $(8,275$ $\mathrm{km}$ ) and provides operators with 16 per cent more cargo volume than the Boeing 747-400 freighter aircraft (Airport Technology, 2021). In addition, the Boeing 747-8 freighter offered a $16 \%$ reduction in fuel usage (Benito \& Alonso, 2018).

\subsection{The Offsetting of Aircraft Related Carbon Dioxide $\left(\mathrm{CO}_{2}\right)$ Emissions}

As previously noted, carbon offset programs are a mechanism available to the world's air cargo carrying airlines to mitigate their carbon footprint. Lufthansa Cargo is one such airline that offers such a program. At the time of the present study, Lufthansa Cargo offered two options for transporting shipments on a more sustainable basis. The first option is based on the use of sustainable aviation fuel (SAF), which is discussed below. The second option is a cargo offset program. Carbon dioxide $\left(\mathrm{CO}_{2}\right)$ emissions are produced during the production and transport of sustainable aviation fuels (SAF), and these emissions can be offset through compensation with environmentally friendly climate protection projects. As a result, the complete carbon dioxide $\left(\mathrm{CO}_{2}\right)$ neutrality of an air cargo consignment can be achieved either by combining both options or alternatively by 100 percent compensation in climate protection projects (Brett, 2021d).

\subsection{The Electrification of Ground Service Equipment (GSE)}

An important side effect of transportation is air pollution from the burning of fossil fuels. Electric powered vehicles can play an important role in improving air quality of transportation services (Longo et al., 2017). It is important to note that the ground service equipment (GSE) used at airports by airlines and ground handling agents to facilitate the turnaround of their aircraft produce harmful emissions, and hence, impact air quality at the airport (Budd, 2017). A solution to this issue is the use of electric powered vehicles and ground service equipment (GSE) (Gellings, 2011). In recent times, electricity powered aircraft loaders have started to replace diesel powered loaders (Ramsay, 2020). Electricity powered aircraft push-back tugs are also available, and there has been a trend among some operators to choose battery-powered aircraft tractors (Airside International, 2020). Electricity powered baggage tractors are also being used at airports, for example, Amsterdam's Schiphol Airport (Airside International, 2021). Air cargo carrying airlines also have the option to acquire and deploy electricity or battery powered air cargo tugs. Stuttgart Airport, for example, operates a fleet of electricity powered 
air cargo tractors. These tractors offer environmental related benefits, which include energy savings, emission reductions and noise reductions (Randall, 2019).

In March 2004, FedEx commenced using some hybrid electric trucks, which the company put into service in Sacramento, California. FedEx Express developed the truck in concert with Environmental Defense and Eaton Corporation, which produced the electric powertrain (Brown \& Jackson, 2004). In 2010, FedEx added allelectric delivery vehicles in Paris and Los Angeles, building on its existing fleet of all-electric delivery vehicles in London. The integration of all-electric vehicles was a key part of the FedEx pledge to improve the fuel efficiency of its vehicle fleet by 20 percent through its Reduce, Replace and Revolutionize strategy (FedEx, 2010). In March 2021, FedEx announced that it would deploy deploying more zero-emission electric trucks for pick-ups and deliveries as part of its foal to achieve carbon neutrality by 2040 (Wolfsteller, 2021).

In the first quarter of 2021, the Deutsche Post DHL Group announced that it will invest $€ 7 \mathrm{bn}$ to reduce its production of carbon dioxide $\left(\mathrm{CO}_{2}\right)$ emissions by 2030. As part of its roadmap to sustainability, the company will acquire and deploy 80,000 e-vehicles to be deployed for last-minute deliveries. This will result in a $60 \%$ electrification of the company's vehicle fleet (Grasso Macola, 2021).

\subsection{The Optimization of Air Traffic Management Procedures}

A further potential measure to reduce the carbon footprint of air carrying airlines is the optimization of air traffic management procedures. Emirates, Singapore Airlines and Cargolux Airlines International are examples of airlines that have worked closely with air traffic service providers to optimize aircraft fuel burn, and thus, the lower the associated emissions.

In 2018, Cargolux participated in the inaugural meeting to establish "continuous descent operations (CDO) at Luxembourg Airport Cargolux subsequently cooperated with the local air navigation service provider (ANSP) to develop CDOs arrivals into Luxembourg (Cargolux International Airlines, 2019). A continuous descent operation (CDO) is one in which the arriving aircraft descends from its cruise level to an airport with its engines at near-idle thrust (Itoh \& Uejima, 2013). With the Cargolux CDO program a number of waypoints on the flight route were established that enable pilots to efficiently plan the descent of their aircraft. Both CDOs and CDAs (Continuous Descent Operations and Approach) methodologies offer the potential for significant fuel savings as well as substantial reduction in carbon dioxide $\left(\mathrm{CO}_{2}\right)$ emissions. For example, a $\mathrm{CDO}(\mathrm{F})$ arrival can provide fuel savings of approximately $250 \mathrm{~kg}$ per flight for a Boeing B747 freighter aircraft, as the engines remain at a near-idle thrust during the process (Cargolux Airlines International, 2019).

In 2010, Cargolux completed a program to equip all aircraft in its own aircraft fleet with the Iridium onboard satellite communications system. The Iridium system offers global coverage, including over the polar regions. As a result, in June 2010, Cargolux aircraft were able to operate on "Future Air Navigation System" (FANS) routes and thereby achieve significant savings in flying time (Cargolux International Airlines, 2011). The reduced flying time provided fuel savings and resulted in lower levels of aircraft emissions. The "Future Air Navigation System" (FANS) is an operational concept which relies upon satellite-based navigation and communication to provide the improvements required in communication, navigation, and surveillance (CNS) to efficiently handle the projected increase in traffic levels (Golmohammad \& Mehdizadeh Dastjerdi, 2012).

Dubai-based Emirates Airline optimizes fuel efficiency in its operations. Once airborne, the airline's flight crew take advantage of opportunities to save aircraft fuel and thus lower emissions where practicable and supported by air traffic control. The airline fuel efficiency measures include continuous aircraft climbs and descents, and inflight rerouting on long-haul flights to consider more favorable shifting winds. Upon landing, the company's pilots use idle reverse thrust (instead of full reverse thrust) and switch off one engine while taxiing to the apron area where it is safe and practicable to do so (Emirates Airline, 2021).

A key focus for Singapore Airlines environmentally sustainable operations has been the adoption of several improved flight operation measures that not only reduce fuel consumption but also the associated carbon dioxide $\left(\mathrm{CO}_{2}\right)$ emissions. These measures include the use "continuous descent" operations, and to minimize fuel use (without impacting safety). In addition, operational procedures that reduce fuel burn for Singapore Airlines Airbus A380 operations have been implemented at London's Heathrow Airport. Singapore Airlines Airbus A380 aircraft departing from Heathrow Airport use less power when taking off, resulting in fuel savings and less carbon dioxide $\left(\mathrm{CO}_{2}\right)$ and nitrous oxide (NOx) emissions. Furthermore, Singapore Airlines optimization of flight operations and flight planning systems have led to more optimum flight route selection (Singapore Airlines, 2017, 2018), and thus, a reduction in carbon dioxide $\left(\mathrm{CO}_{2}\right)$ emissions. 


\subsection{The Use of Electric Powered Aircraft}

United Parcel Service (UPS), as part of its environmental commitment, ordered vertical takeoff and landing electric (eVTOL) aircraft in April 2021. The aircraft that UPS are acquiring are the ALIA-250c, which is manufactured by Beta Technologies. With a flying range of 402 kilometres and cargo volume of 5.66 cubic metres (635 kilograms capacity), these aircraft will be limited to carrying smaller loads. These new aircraft will replace ground transport, which takes longer, and small feeder aircraft, which are more polluting and require airports for takeoff and landing. UPS has placed firm orders 10 eVTOL aircraft and UPS have the option to increase the purchase from Beta to 150 aircraft. These aircraft will require recharging, and UPS has also reserved Beta's recharging station allowing for a rapid recharge in under an hour, which is sufficient time for the aircraft to be unloaded and reloaded ready for the next flight (Humphries, 2021). UPS is expected to take delivery of the first ten aircraft in 2024 (Reichmann, 2021b).

In August 2021, DHL's air cargo subsidiary DHL Express, announced an order of 12 all-electric powered aircraft from Seattle-based manufacturer "Eviation". These new aircraft will be added to the company's fleet of powered vans and bikes. Once they enter service in 2024, the aircraft are scheduled to be operational on DHL Californian routes. According to DHL, the electrification of every transport mode plays a critical role and will significantly contribute to the company's overall sustainability goal of zero emissions. The aircraft will be flown by a single pilot and will only require 30 minutes or less to charge per hour of flight, carrying a maximum of $1,200 \mathrm{~kg}$ over a range of 815km (DHL Group, 2021; Grasso Macola, 2021). DHL plans to operate its fleet of 12 electric planes for the middle-mile transportation of packages from major air hubs to smaller markets (Holland, 2021).

In September 2021, SAMAD Aerospace, a green technology start-up company based in the United Kingdom, announced that it has commenced the certification process for its Starling Cargo aircraft. The electrically powered aircraft will have a cruising speed of $95 \mathrm{mph}(152 \mathrm{kh})$, a flight ceiling of 10,000 feet $(3,048$ metres) and a range of up to 135 miles (217.2 kilometres). The electric vertical take-off and landing aircraft will provide operators with the flexible point to point delivery of air cargo up to its 50-kilogram payload. The potential market segments for this aircraft are the air cargo industry that need to transport high value cargo. These include oil and gas firms, gemstone mining companies, medical logistics and emergency response companies. In addition, the new aircraft can be used for delivering humanitarian critical cargo of urgently required food, medicine, and equipment to often remote regions of the world which has underdeveloped or damaged local infrastructure (Holland, 2021; Turner, 2021e).

The substitution of jet fuel with electricity can influence the impact of aviation services on climate change, as electric powered aircraft do not produce any carbon dioxide $\left(\mathrm{CO}_{2}\right)$ emissions from fuel combustion. Importantly, however, these carbon dioxide $\left(\mathrm{CO}_{2}\right)$ benefits need to be considered on a life-cycle basis and will only occur if the electrical energy is sourced from lower carbon sources (Shah, 2021).

\subsection{The Use of Fixed Electrical Ground Power at Airports}

In addition to the carbon dioxide $\left(\mathrm{CO}_{2}\right)$ emissions generated by aircraft, aircraft ground operation carbon dioxide $\left(\mathrm{CO}_{2}\right)$ emissions can also be significant at airports (International Airport Review 2010). A variety of handling activities are undertaken at airports. The activities associated directly with the aircraft itself include the provision of power, cleaning, loading, or unloading of baggage/air cargo, lavatory services, aircraft marshalling, aircraft towing or pushback, and aircraft fuelling (Ashford et al., 2013; Kazda \& Caves, 2015; Thompson, 2007). Consequently, electrical power is required on the airport apron to facilitate the aircraft turnaround process. External electrical power is also often used for aircraft engine startup. Hence, to minimize aircraft auxiliary power unit (APU) usage, many airports provide aircraft electric power (and cooling capabilities) at the gate which are more efficient and cleaner than APUs powering generators and cooling packs (de Neufville \& Odoni, 2013). An aircraft's auxiliary produces harmful emissions (Baxter, 2021). Thus, airports can help reduce aircraft emissions at airports through the provision of fixed electrical ground power (FEGP) and preconditioned air (PCA) to enable aircraft auxiliary power unit (APU) shutdown. In addition, to satisfy more stringent regulations on the supply of power at aircraft stand, operators and manufacturers are increasingly working towards smarter, more efficient, and more environmentally friendly usage and deployment of power units (Airside International, 2012). The use of fixed electrical ground power (FEGP) stations (and the supply of preconditioned air supply) eliminates the requirement for airlines to use APU's whilst the aircraft is at the gate (Bartsch, 2013; Elmer \& Leigland, 2014; Yim et al. 2013). Many airports are now suppling electrical power from central power supplies that connect to the aircraft either by apron cable or by cable in the aerobridge structure (Ashford et al. 2013). Thus, the use of fixed electrical ground power (FEGP) and preconditioned air eliminates these harmful emissions from the environment (Baxter, 2021). 
Nowadays, many air cargo carrying airlines are using fixed electrical ground power (FEGP) and pre-cooling) and this will help reduce their carbon footprint. Emirates Airline, for example, prioritizes the use of ground power and pre-conditioned air where it is available so that the aircraft's auxiliary power unit does not have to be used. This measure helps to save fuel and reduces their associated airborne emissions (Emirates Airline, 2021). Singapore Airlines also uses mobile ground power units and preconditioned air units during night layovers and long transits to reduce the reliance on its aircraft auxiliary power units (APUs) (Singapore Airlines, 2017, 2019).

\subsection{The Potential Use of Hydrogen as an Aircraft Energy Source}

At the time of the present study, hydrogen was being considered for future use in energy generation within the aviation industry due to its cleanness and abundance of supply (Baroutaji et al., 2019; Xu et al., 2015). Hydrogen powered aircraft can provide important environmental benefits as this energy source can substantially reduce or even eliminate aircraft pollutants, thus mitigating the impact on the environment (Schutte et al., 2016). Because of its environmental benefits, hydrogen is regarded as being a very likely energy source for the future of aviation, as it is a fuel source that has the potential of zero emissions (Khandelwal et al., 2013). However, the implementation of hydrogen technology has many technical challenges to overcome, including the development of sustainable production, storage and delivery systems that shall not diminish the environmental benefits of this fuel source (Rondinelli et al. 2017).

ASL Aviation Holdings in October 2021 announced its plan to purchase ten hydrogen-propulsion "conversion kits" for use on its ATR turboprop aircraft. Universal Energy is developing the hydrogen conversion kits as part of a broader effort to stimulate the use of hydrogen propulsion for aviation. ASL Aviation Holdings will be a global launch customer for the turboprop air cargo market and the company plans to purchase up to ten of Universal Hydrogen's ATR 72 conversion kits for installation into its existing or future turboprop aircraft fleet (Brett, 2021c).

\subsection{The Use of Lightweight Aircraft Unit Load Devices}

In addition to the aircraft unit load devices (ULDs) used to carry passenger baggage (Airline Ground Services 2013), airlines also use ULDs for the carriage of air cargo and mail, such as containers and pallets (Lu \& Chen, 2012). Aircraft unit load devices (ULDs) are pallets and containers which are used to carry air cargo, mail and passengers' baggage on wide-body passenger and dedicated freighter aircraft (Baxter et al., 2014; Lu \& Chen, 2011). Combination airlines who operate freighter aircraft, for example, Cathay Pacific Airways and Qatar Airways, dedicated all-cargo airlines, and the integrators, also use specially designed containers to fit the main deck of their freighter aircraft (Coyle et al. 2011; Morrell \& Klein, 2018). In recent years airlines from all around the world have been seeking ways to become more fuel efficient so they can minimize their operational costs whilst at the same time mitigating their impact on the environment. One feasible way of achieving these objectives and minimizing weight without compromising the business volume is using light weight aircraft unit load devices (ULDs) (Laniel et al 2011). Thus, the increasing use of lightweight aircraft unit load devices (ULDs) is being driven by airline requirements to save on fuel costs and reduce the carbon dioxide $\left(\mathrm{CO}_{2}\right)$ impact within the industry (Airline Ground Services, 2013).

In 2012, Etihad Airways, together with its Unit Load Device (ULD) partner Jettainer, embarked on a program to replace 3,000 aircraft containers from the airline's original aluminium ULD fleet with more environmentally friendly lightweight versions. The airline estimated that the use of the new lightweight aircraft containers would reduce annual carbon dioxide $\left(\mathrm{CO}_{2}\right)$ emissions by approximately 5,000 tons per year (Times Aerospace, 2012). In August 2012, Airberlin began modernizing its aircraft container fleet with lightweight aircraft containers. These containers are used to transport air cargo consignments and passengers' baggage. The use of the lightweight containers has reduced the actual flight weight by 200 kilograms, saving about 30,000 litres of fuel per year per aircraft. This enabled the airline to reduce its annual carbon dioxide $\left(\mathrm{CO}_{2}\right)$ emissions by 1,100 tonnes (Aviation Pros, 2012).

In 2013, FedEx finished retrofitting or replacing approximately 23,000 older-model aircraft ULDs, with more efficient lightweight containers. The use of new lightweight containers enabled FedEx to reduce its annual carbon dioxide $\left(\mathrm{CO}_{2}\right)$ emissions by around 35,289.4 tonnes per year (Lee, 2013). Swiss WorldCargo began replacing some of its unit load devices (ULDs) with state-of-the-art, lightweight containers during 2013. The airline's entire $\mathrm{XKN}$ container fleet, which are used for the transportation of valuables on long-haul routes, was replaced with AVA containers provided by outsourced ULD management company Jettainer. The new AVA containers are constructed of carbon fibre as well as partly recycled composite materials. These containers are around 40 kilograms lighter than the XKN containers previously used by the airline. This significant weight reduction resulted in an improved payload, increased fuel efficiency, as well as the reduction in the airline's annual carbon dioxide $\left(\mathrm{CO}_{2}\right)$ emissions (Air Cargo News, 2013b). Etihad Airways and Jettainer partnered together in 2013 to launch a new 
lightweight and double-width unit load device (ULD), known as the type ALF container. The new ALF container is almost 34 per cent lighter at 130 kilos, a saving of 66 kilos per unit, and offers a potential weight saving of 116 kilos per flight. Etihad predicted that the use of these new containers would offer an annual reduction in carbon dioxide emissions of 4,000 tonnes (Air Cargo News, 2013a).

On February 11, 2014, Nordisk Aviation Products completed the delivery of more than 4,300 light weight air cargo containers to Singapore Airlines. These new light weight containers helped the airline to save a minimum 77,600 kilograms on its ULD fleet (Nordisk Aviation Products, 2014). In May 2014, Japan Airlines acquired 480 new light-weight cargo containers for use on its international network. An important benefit for the airline was that the weight of new light weight containers was $40 \%$ lower, and this helped to reduce fuel consumption and the associated emissions (Japan Airlines, 2014). Since 2014, Finnair Cargo has acquired lighter-weight cargo pallets and the weight savings have delivered an environmental benefit to the airline (Salmi, 2019).

In 2015, Cargolux Airlines International became the first airline to carry cargo handling systems manufacturer Telair International's CAEROe ${ }^{\circledR}$ advanced lightweight unit load devices (ULDs). The all-cargo airline began using CAEROe ${ }^{\circledR}$ 's cookie sheet pallets, heavy gross weight pallets and fuel-saving containers on its fleet of Boeing B747 freighter aircraft. The pallets are up to 40 per cent lighter than standard aluminum ULDs. The use of the new light weight pallets and containers enabled Cargolux to reduce aircraft fuel burn and its annual carbon footprint (Air Cargo News, 2015a). Jettainer, a aircraft ULD leasing company, began the development of a new lightweight aircraft pallet in 2015 . The new pallet weighs $70 \mathrm{~kg}$, which is approximately $32 \mathrm{~kg}$ lighter than a traditional PMC aluminium unit. The new pallet is made of a composite material that was applied for the first time in the aviation sector. The new pallet offered airlines with an alternative to using thinner aluminium bases to reduce aircraft weight (Air Cargo News, 2015g), and thus, aircraft fuel burn. In 2015, Lufthansa Cargo reduced its fuel consumption by 2,000 tonnes per year and reduced carbon dioxide $\left(\mathrm{CO}_{2}\right)$ emissions by 7,000 tonnes from the use of light weight containers, that were made from lighter composite materials These new containers have a $14 \mathrm{~kg}$ weight saving over conventional AKE containers (Air Cargo News, 2015e). Portuguese flag carrier TAP Portugal began replacing its fleet of 3,500 Unit Load Devices with lightweight units as part of an outsourcing deal with CHEP Aerospace Solutions in 2015. As well as reducing aircraft fuel consumption, the significant reduction in container weight was anticipated to reduce TAP's carbon emissions by 11000 tonnes over the four-year contract term (Air Cargo News, 2015d). On October 8, 2015, United Cargo announced a plan to purchase 8,500 Herculight $\mathrm{S}$ containers that were developed by Zodiac Aerospace, which will completely replace its current fleet of AKE baggage and cargo containers. United Airlines became the launch customer for the Herculight $S$, which weighs less than $55 \mathrm{~kg}$, a reduction of $36 \mathrm{~kg}$ on the traditional AKE container. The switch to lighter containers was expected to reduce the airline's fuel consumption by two million gallons a year when completed, thus cutting the airline's annual carbon dioxide $\left(\mathrm{CO}_{2}\right)$ emissions by more than 19,400 tonnes (Air Cargo News, 2015f). As part of its goal to reduce its annual carbon footprint, Air France-KLM Air France-KLM have introduced new lightweight aluminum pallets that are $17 \mathrm{~kg}$ lighter than standard pallets used by the two airlines. The new $83 \mathrm{~kg}$ pallets gradually replaced all the current standard stock - each weighing 100kg - in the airline's fleet (Air Cargo News, 2015b). CHEP Aerospace Solutions signed a five-year agreement in 2015 to supply and manage Hong Kong-based Cathay Pacific Airways unit load device (ULD) fleet and pallet accessories. As part of this agreement CHEP Aerospace Solutions acquired Cathay Pacific's fleet of 25,000 ULDs, converting the majority to these to modern light weight composite units weighing $58 \mathrm{~kg}$ (Air Cargo News, 2015c).

In 2016, Fiji-based Fiji Airways signed a contract with CHEP Aerospace Solutions whereby CHEP introduced new lightweight containers from its 80,000 pool of assets to support Fiji Airways in reducing fuel costs and lowering the airline's carbon dioxide $\left(\mathrm{CO}_{2}\right)$ emissions. This initiative helped towards Fiji Airways sustainability targets (Air Cargo News, 2016b). Oslo-headquartered low-cost carrier (LCC) Norwegian Air Shuttle introduced new, lighter, and stronger baggage and cargo containers for use onboard its Boeing 787 'Dreamliner' aircraft in 2016. These new lighter weight containers were acquired to help improve the airline's fuel efficiency (Air Cargo News, 2016c). Scandinavian Airline (SAS) extended its contract with ULD service provider CHEP Aerospace Solutions in 2016, and as part of this contract, SAS began using CHEP's lightweight $65 \mathrm{~kg}$ containers. These containers were over $20 \%$ lighter than the airline's existing units and as a result SAS saved over 13,000 tonnes of carbon dioxide $\left(\mathrm{CO}_{2}\right)$ over the five-year term of the new contractual agreement (Air Cargo News, 2016d). Also, in 2015, Jettainer replaced Italy-based Alitalia's entire fleet of 650 AKE containers, that were used for carrying belly hold freight and luggage on passenger aircraft, with the state-of-the-art, lightweight containers, as part of the contract between the two companies. The new replacement ULDs reduce each of the 
existing Alitalia containers' weight by 20 per cent - from 82 kilograms to a maximum of 66 kilograms. The weight reduction resulted in a significant reduction in fuel consumption and in turn lower carbon dioxide $\left(\mathrm{CO}_{2}\right)$ emissions (Air Cargo News, 2016a).

In 2017, Brussels Airlines converted its entire baggage and air cargo container fleet to new lightweight composite containers. This was done in partnership with CHEP Aerospace Solutions. The move by the airline to use lightweight containers was driven by the requirement to save on fuel costs and to reduce its carbon dioxide $\left(\mathrm{CO}_{2}\right)$ emissions (Airline Routes and Ground Services, 2018).

In 2019, aircraft ULD leasing firm Jettainer teamed up with Trilatec to offer a new lightweight pallet load distribution system that weighs approximately $80 \%$ less than traditional system. The trilatec squAIR-timber system, which is made of cardboard fibre, aims to replace the wooden planks that are frequently used for load distribution on airfreight pallets. The weight saving of approximately $80 \%$ leads to substantial reductions in fuel consumption and helps to reduce carbon dioxide $\left(\mathrm{CO}_{2}\right)$ emissions (Brett, 2019).

Virgin Atlantic Airways has acquired a fleet of light weight aircraft unit load devices (ULDs), which have enabled the airline to lower its carbon dioxide $\left(\mathrm{CO}_{2}\right)$ emissions by around 2,000 tonnes per year (Putzger, 2015).

In sum, the trend by airlines towards the use of new lightweight aircraft unit load devices (ULDs) has been underpinned by their objective to reduce aircraft fuel burn and the associated carbon dioxide $\left(\mathrm{CO}_{2}\right)$ emissions.

\subsection{The Use of Sustainable Aviation Fuels as an Industry Decarbonization Related Measure}

The use of sustainable aviation fuels (SAF) has been identified as one of the key elements in helping the world's airlines to achieve their goal of decarbonizing their operations. At the time of the present study, more than 45 airlines had trialed the use of sustainable aviation fuel. Since 2016, more than 370,000 flights have been operated with sustainable aviation fuel (International Air Transport Association, 2021a). The first step towards a carbon-free future for the air cargo industry is carbon-neutral growth, which implies that there should be no increase in carbon dioxide $\left(\mathrm{CO}_{2}\right)$ emissions despite the growth in air cargo traffic. Hence, making investments in sustainable aviation fuel (SAF) is viewed as a necessary step in this process and one of the primary instruments in reducing the industry's carbon dioxide $\left(\mathrm{CO}_{2}\right)$ emissions (Turner, 2021f). Considering the key role that sustainable aviation fuels will play in decarbonizing air cargo transportation, air cargo carrying airlines have developed sustainable aviation (SAF) programs, which are being offered to air freight forwarders, logistics service providers, and air cargo shippers.

Air France, KLM, and Martinair Cargo launched the world's first sustainable aviation fuel (SAF) program for the air cargo industry in December 2020. In June 2011, KLM operated the world's first commercial flight using sustainable aviation fuel (SAF), from Amsterdam Airport Schiphol to Paris Charles de Gaulle. A key objective of this program is to enable both shippers and air freight forwarders to stimulate and enlarge the market for sustainable aviation fuels (SAF) (Brett, 2020; Rimoczi, 2020; Turner, 2020). The sustainable aviation fuel program offered by Air France KLM Martinair Cargo (AFKLMP Cargo) enables shippers and air freight forwarders to select how much of their air cargo consignments will be flown on flights powered by sustainable aviation fuel (Air Cargo News, 2021c), which as noted earlier is a cleaner substitute for conventional jet fuel, thus reducing carbon dioxide $\left(\mathrm{CO}_{2}\right)$ emissions by up to $85 \%$ (Turner, 2021c). Bolloré Logistics joined the Sustainable Aviation Fuel (SAF) program offered by Air France KLM Martinair Cargo (AFKLMP Cargo) in January 2021. The agreement covered its shipments between Paris Charles de Gaulle and New York John F. Kennedy airports. It was anticipated that this agreement would reduce carbon dioxide emissions by $50 \%$ on this trade lane (Finn, 2021; Global Cargo Insight, 2021). Global transport and logistics services provider, Kuehne+Nagel partnered with Air France KLM Cargo in January 2021 to launch the first carbon neutral air freight lane between North America and Europe. In accordance with the agreement, $100 \%$ sustainable aviation fuel (SAF) will be used on Kuehne+Nagel cargo shipments carried on board Air France-KLM flights from Los Angeles to Amsterdam (Grover, 2021). On April 21, 2021, Koppert Biological Systems and Air France KLM Martinair Cargo (AFKLMP Cargo) entered into a partnership agreement covering the use of sustainable aviation fuel (SAF) on selected international cargo flights that transport Koppert's agricultural and horticultural products for biological pest control (Air Cargo Week, 2021; Koppert Biological Systems, 2021). In May 2021, Marinetrans (MT) joined the Sustainable Aviation Fuel (SAF) program of Air France KLM Martinair Cargo (AFKLMP Cargo) for its 2021 marine logistics shipments (Marinetrans, 2021). Best Global Logistics (BGL) and Dutch air freight forwarder Fast Forward Freight (FFF) also joined the program in May 2021 (Brett, 2021h). In June 2021, Airpharm Logistics SAU became the first Spanish-based air freight forwarder to join the Air France KLM Martinair Cargo (AFKLMP) Sustainable Aviation Fuel (SAF) program (Biofuels International, 2021a). Also, in June 2021, the Middle East South Asia (MESA) operation of Hellmann Worldwide 
become the first freight forwarder and logistics service provider in the region to join the Air France KLM Martinair Cargo (AFKLMP Cargo) Sustainable Aviation Fuel (SAF) program (Graham, 2021a; Times Aerospace, 2021). In July 2021, freight forwarders and logistics service providers AWOT Global Express, CTS International Logistics Corporation, Job-Mate International, Sinotrans e-Commerce Logistics and Xiamen Supertrans joined the Sustainable Aviation Fuel Program (SAF Program) offered by Air France KLM Martinair Cargo (AFKLMP Cargo). The use of sustainable aviation fuels enabled greener air cargo services on routes connecting China with Europe and South America (Harry 2021a; Saunders, 2021a; Turner, 2021d). In September 2021, Total Touch Cargo Holland BV (TTC) and Air France KLM Martinair Cargo (AFKLMP Cargo) ratified a partnership agreement as part of the airline's sustainable aviation fuel (SAF) program. Under the deal, AFKLMP Cargo will use sustainable aviation fuel (SAF) on selected cargo flights from Nairobi, Kenya, to Amsterdam Airport Schiphol. These flights carry TTC's fresh agricultural and horticultural products (Biofuels International, 2021b; Saunders, 2021b). Airflo and Tiger Freight joined the Air France, KLM and Martinair sustainable aviation fuel (SAF) program in November 2021. The sustainable aviation fuel (SAF) partnership agreement will make it possible to use sustainable aviation fuel on AFKLMP Cargo flights from Kenya and Zimbabwe carrying Airflo's and Tiger Freight's fresh agricultural and horticultural products. Thus, Airflo and Tiger Freight will be able to reduce the carbon dioxide $\left(\mathrm{CO}_{2}\right)$ emissions that they produce on their flowers and perishables air cargo consignments (Keen, 2021; Turner, 2021a).

All Nippon Airways (ANA) launched its "SAF Flight Initiative" on 24 October 2021. The aim of the program is to reduce carbon dioxide $\left(\mathrm{CO}_{2}\right)$ emissions. The new program was designed to promote Sustainable Aviation Fuel (SAF) through the collaboration with leading companies in this area. The program was the airline's latest effort to decrease its carbon footprint and adhere to the guidelines established by the United Nations Sustainable Development Goals (SDGs) as well as meet ANA Group's environmental commitments. Nippon Express Co., Ltd., Kintetsu World Express, Inc. and Yusen Logistics Co., Ltd. also announced that they would participate in the SAF Flight Initiative. ANA conducted a SAF-powered cargo flight in conjunction with these three major logistics and cargo companies on September 29. This was the first flight by a Japanese airline to conduct a joint operation using sustainable aviation fuel (SAF) (All Nippon Airways, 2021; Turner, 2021b).
Bolloré Logistics introduced a sustainable aviation fuel (SAF) program in July 2021. With this program, customers can reduce their carbon dioxide $\left(\mathrm{CO}_{2}\right)$ emissions by $80 \%$ (Brett, 2021d).

Cargolux Airlines International, one of the world's major dedicated all-cargo airlines, announced the launch of its sustainable aviation fuel (SAF) program on 25 October 2021. The introduction of the airline's sustainable aviation fuel (SAF) program is a key part of the airlines plan to decarbonizing its operations. The airline aims to be carbon neutral by 2050 (Cargolux Airlines International, 2021). The new program is designed to reduce the airline's carbon dioxide $\left(\mathrm{CO}_{2}\right)$ emissions and will help underpin its customer sustainability program, that will offer more sustainable options for customer transportation requirements (Saunders, 2021c).

CEVA Logistics became a member of United Airlines sustainability initiative, the "Eco-Skies Alliance" in April 2021. CEVA Logistics together with the other "Eco-Skies Alliance" companies are working with United Airlines to collectively purchase approximately 3.4 million gallons of sustainable aviation fuel (SAF) during 2021 (Harry 2021c).

DHL Express, one of the world's major integrated carriers, signed an agreement with energy firm Shell Aviation during December 2020 that will see it being supplied with sustainable aviation fuel (SAF) to power DHL Express flights from Amsterdam Schiphol Airport. This agreement formed part of DHL Express goal to achieve net zero emissions by 2050 (Harry, 2020b).

DHL Global Forwarding, the world's largest air freight forwarder, joined United Airlines sustainable aviation fuel (SAF) program in May 2021. As part of United Airlines "Eco-Skies Alliance program", DHL Global Forwarding will contribute towards the purchase of 3.4 million gallons of sustainable aviation fuel (SAF) during 2021. The reductions in DHL Global Forwarding carbon footprint are subsequently allocated by DHL to its customers (Brett, 2021e).

Logistics service provider Geodis began to offer its customers more sustainable transportation options for their air cargo shipments in September 2021. The company's customers can ship their air cargo consignments on flights that are partially powered by sustainable aviation fuels (SAF), thus enabling them to reduce their carbon footprint (Air Cargo News, 2021b; Harry, 2021d).

IAG Cargo partnered with Kuehne+Nagel $(\mathrm{K}+\mathrm{N})$ in June 2021 to complete its first net zero charter chain. This comprised 16 charter flights, that used sustainable aviation fuel (SAF). The charters operated between Stuttgart and Atlanta and were the first time that passenger-freighter 
flights were operated with net-zero carbon emissions (Harry, 2021e).

Kuehne+Nagel entered into an agreement with American Airlines in March 2021 to use 11 million litres of sustainable aviation fuel (SAF) for the transportation of its air cargo consignments. The agreement is part of $\mathrm{K}+\mathrm{N}$ 's "Net Zero Carbon program". Under the terms of the agreement, American Airlines will allocate a portion of the carbon reduction benefit generated through its use of sustainable aviation fuel (SAF) to Kuehne+Nagel (Harry, 2021f). Kuehne+Nagel and Lufthansa Cargo agreed on a partnership agreement in October 2021 for the promotion and use of power-to-liquid (PTL) synthetic sustainable aviation fuel (SAF). The two companies will purchase 25,000 litres of the fuel per year from what will become the world's first production site for synthetic crude oil in Werlte/Emsland in Germany (Brett, 2021f). Prior to this partnership agreement, Kuehne+Nagel and Lufthansa Cargo have used bio-based sustainable aviation fuels (SAF) to reduce the carbon footprint of air cargo consignments tendered for carriage by Lufthansa Cargo (Brett, 2021c). Kuehne+Nagel $(\mathrm{K}+\mathrm{N})$ began offering its customers with the option to purchase sustainable aviation fuel (SAF) for shipments so that customers can reduce the environmental impact of supply chains (Brett, 2021g). With the newly launched offering, all Kuehne+Nagel customers can easily request the use of sustainable aviation fuel (SAF) to be used instead of fossil fuel for air transport, and thus, they benefit from net zero carbon emissions air freight services. Sustainable aviation fuels (SAF) still produce some carbon dioxide $\left(\mathrm{CO}_{2}\right)$ emissions, thus under this program carbon neutrality is achieved by substituting each litre of jet fuel kerosene used with 1.33 litres of sustainable aviation fuel (SAF) (Turner, 2021c).

Lufthansa Cargo and DB Schenker teamed together on November 29, 2020, to operate the first ever carbon dioxide $\left(\mathrm{CO}_{2}\right)$-neutral freighter flights, powered by sustainable aviation fuel (SAF). The flight operated from Frankfurt to Shanghai utilizing a Lufthansa Cargo Boeing 777 freighter aircraft (Harry, 2020a). In April 2021, DB Schenker and Lufthansa Cargo partnered together to launch a regular carbon dioxide $\left(\mathrm{CO}_{2}\right)$-neutral freighter route, operating between Frankfurt and Shanghai (Air Cargo News, 2021a; Harry, 2021b). The use of sustainable aviation fuel has reduced conventional kerosene usage of 174 tonnes per week on this route (Harry, 2021b). In October 2021, Nokia Telecommunications joined the Lufthansa Cargo and DB Schenker sustainable aviation fuel (SAF) initiative. Each week, the global telecommunication network provider will avoid greenhouse gas (GHG) emissions by using the world's only freighter flight that is 100 percent powered by sustainable aviation fuel (SAF) (DB Schenker, 2021). In 2021, Lufthansa Cargo began to offer all its customers the option of carbon dioxide $\left(\mathrm{CO}_{2}\right)$ neutral transportation on segments that are operated by freighter aircraft. Lufthansa Cargo will achieve the carbon dioxide $\left(\mathrm{CO}_{2}\right)$ neutrality by using sustainable aviation fuel (SAF) or as noted earlier, through certified carbon offsetting projects which will avoid or compensate for the emissions generated during air cargo transportation (Brett, 2021g).

In September 2021, the United States government announced its goal of replacing all jet fuel with sustainable alternatives by 2050 . The government's plan is to substantially boost the production of fuels made from waste or plants to reduce the environmental cost of aircraft emissions. The government's new goal targets the annual production of 3 billion gallons of sustainable fuels by 2030 . This will provide a $20 \%$ reduction in aircraft carbon dioxide $\left(\mathrm{CO}_{2}\right)$ emissions. United States-based airlines have set a target of producing 2 billion gallons of alternative fuels by 2030 (Fried, 2021).

\subsection{The Use of Renewable Energy Sources for Ground Based Buildings and Facilities}

Airlines are extremely energy intensive. This is because airlines use very large amounts of power and heating and cooling for their buildings and facilities (Baxter et al., 2021a). The traditional power source used by airlines is electricity, which is typically sourced from the local grid. Air cargo carrying airlines could consider, where climatic conditions permit, the use of "green" or renewable energy sources. Renewable energy sources reduce air pollution and cut down carbon dioxide $\left(\mathrm{CO}_{2}\right)$ emissions (Spellman, 2015; United Nations, 2018; United States Energy Information Administration, 2021). Furthermore, the use of solar power helps a firm to mitigate its greenhouse gases (GHGs) and achieve it sustainability objectives (Sreeneth et al., 2021). The use of green or renewable energy sources provides a firm or user with an important opportunity to optimize their energy efficiency (Arman et al., 2013). A further advantage is that renewable energy sources generally have very little waste (Yerel Kandemir \& Yayli, 2016).

FedEx Express, the world's largest air cargo carrying airline, has adopted the use of renewable energy as part of its environmental policy. On October 18, 2004, FedEx announced the plan to build a 904-kilowatt solar array that would provide about $80 \%$ of the peak load demand for FedEx Express' Oakland facility (Brown \& Jackson, 2004). In August 2005, FedEx solar-electric system at its regional hub in Oakland, California became operational. The system can generate around 1 million kilowatt hours (KWh) of clean energy each year. The system can provide 20 percent 
of the airline's cargo facility's total electricity needs and meet 80 percent of its peak load demand. On October 20, 2008, FedEx commenced work on the installation of a 1.4megawatt solar power system that would generate 1.3 gigawatt hours of electricity per year at its Cologne Hub in Germany (Jackson, 2008). On October 27, 2010, the photovoltaic (PV) solar system became operational, and the system can produce around 800,000 kWh per year (FedEx, 2010). FedEx announced plans to install its largest rooftop solar-electric system at its distribution hub in Newark, New Jersey on October 17, 2002. Upon completion, the system had the capacity to generate approximately 2.4 million kilowatt hours (kWh) and would provide over 15 percent of the hub's energy needs. In addition, the new photovoltaic (PV) enabled FedEx to reduce its carbon dioxide $\left(\mathrm{CO}_{2}\right)$ by around 1,807 tonnes per annum (FedEx, 2012). FedEx Freight has also completed installed solar electric systems at its California facilities in Whitter and Fontana. In Geneva, Switzerland, a FedEx cargo facility uses a system of pipes running deep into the ground to warm the building's air in winter and cool it in the summer. The system reduces the cargo terminal's reliance on gas for heating or freon for cooling, and thus, requires less energy to operate (Jackson, 2008)

Finnair's photovoltaic (PV) solar system, that had been installed on the Finnair's Cool Cargo terminal at Helsinki's Vantaa Airport, came online in 2018 generating electricity for the airline's air cargo terminal. During 2018, the solar panels produced $287 \mathrm{MWh}$ of electricity (Finnair, 2019). In 2019, the system produced 297 MWh of power for the terminal's own use. This represented $8.7 \%$ of the total energy consumption of the air cargo terminal building (Finnair, 2020).

Singapore Airlines, a major air cargo carrying airline, has adopted the use of renewable energy. As part of this strategy, Singapore Airlines has entered a partnership with SembCorp Solar to install rooftop solar panels on three of its Singapore-based buildings: Airline House, SIA Training Centre and TechSQ. It was envisaged that the solar panels would come online in the second quarter of FY2020/21, and they would generate a projected 5,382 $\mathrm{MWh}$ of renewable energy annually, which is able to support up to 18 per cent of the company's buildings' electricity demand (Singapore Airlines, 2020). The installation of the solar panels on all its office buildings in Singapore was completed in the 2020/21 financial year. As well as delivering considerable energy savings, the new system has reduced the airline's carbon dioxide $\left(\mathrm{CO}_{2}\right)$ emissions by 4.3 million tonnes a year (Singapore Airlines, 2021).

\subsection{The Use of Sustainable Waste Management Principles}

In providing air transport services, airlines generate a substantial amount of comingle waste (Blanca-Alcubilla et al., 2019). Solid waste management and the disposal of wastes has therefore become one of the most significant issues in the environmental management of the world airline industry (Li et al., 2003). Accordingly, airlines are making substantial efforts to improve their waste management and reduce waste generation wherever possible (Blanca-Alcubilla et al., 2019). In providing air cargo services, airlines generate various types of waste which includes tyres, fluids from equipment, universal wastes (light bulbs, electronics, and batteries), wood and wooden pallets as well as plastic packing material. In addition to the general and food waste generated from offices, other significant sources of waste are plastic packing material and wood and wooden pallets (United States Federal Aviation Administration, 2013).

Waste avoidance refers to the measures that need to be implemented prior to a substance becoming waste (International Civil Aviation Organization, 2021). In an ideal situation, waste would be avoided. This means that in the waste management hierarchy, reducing or preventing waste should be the primary objective of the firm. A firm can reduce its wastes by implementing two key strategies. The first strategy involves the firm reducing the volume of waste generated and disposed to landfill. In following this strategy, the firm reduces the impact of wastes on the environment, it reduces the emissions generated from the wastes disposed in landfills and offers the firm energy and natural resources savings (Zhu et al., 2008). The second strategy involves the firm adopting an effective system to manage all unavoidable waste (Baxter et al., 2018).

There are four principal waste disposal methods available to airlines: composting, recycling, incineration (including waste to energy), or disposal of wastes to landfill (Baxter et al., 2021b). Composting waste is a process in which the organic portion of solid waste is converted into a humuslike product. The final product, which is inert in nature, can be utilized as a soil conditioner or used for landfill cover (Harper, 2004, p. 3). There are two key environmental related advantages associated with the composting of rubbish. First, there are lower levels of environmental pollution from the composting of wastes. Secondly, there is the beneficial use of the end products (Taiwo, 2011).

The incineration of solid waste has two particularly useful purposes in a waste management system. Primarily, it reduces the volume of waste to be disposed of by sanitary landfill (Rand et al., 2000). Secondly, incineration can also be used as a means of generating energy (Awasthi et al., 
2019; Hettiarachchi \& Kshourad, 2019). Energy recovery reduces the volume of waste that is disposed by landfill and produces useable energy, in terms of heat, electricity or fuel, through a variety of processes. These processes include combustion, gasification, pyrolysis, and anaerobic digestion (Rahman et al., 2017).

When recycling waste, the waste fraction is utilized again to produce consumer goods or other products. Recycling of wastes may also include the conversion of waste into energy through thermal treatment (processing). Disposal in landfill sites is regarded as the least desirable waste disposal option (Manahan, 2011; Pitt \& Smith, 2003). Waste that is disposed of through landfilling and open dumping, is regarded as being environmentally unsafe due to emission of greenhouse gases (GHGs) (Ahmed et al., 2020; Trabold \& Nair, 2019).

Air cargo carrying airlines could also adopt the circular economy waste management approach. The circular economy is an economic system that is based upon business models that replace the "end-of-life" concept with reducing or alternatively reusing, recycling, and recovering materials during the product/distribution and consumption processes of a firm (Ginga et al., 2020). The circular economy extends beyond recycling and is based upon a restorative industrial system that focuses on the treatment of waste as a resource (Ghosh, 2020). The circular economy is comprised of three primary activities: the reduction in the use of virgin raw materials, the re-use of already processed materials, and the recycling of waste. In some instances, there is a fourth circular economy activity, that of the redesign of products (Burneo et al., 2020; Kyriakopoulos et al., 2019). For a firm to achieve the benefits of a circular economy approach, the following steps need to be undertaken reuse, recycling, recovery, and waste prevention (Kyriakopoulos et al., 2019). A circular economy waste management approach respects the firm's environmental boundaries through an increase in the share of renewable or recyclable resources whilst at the same reducing the consumption of raw materials and energy. With this approach, emissions and loss of resources are thereby reduced (European Environment Agency, 2016).

Finnair, LATAM Airlines, and Singapore Airlines are examples of airlines that have adopted the circular economy approach to waste management.

\subsection{Washing of Aircraft Engines}

A further decarbonization measure available to air cargo carrying airlines is the washing the engines of their aircraft fleet. All aircraft engines become soiled during normal operations by airborne contaminants such as sand, dust, soot, salt, insects, and pollution. These contaminants can result in aircraft engines not operating efficiently, and, as a result, can lead to overall deterioration in engine health Because of this an engine burns more fuel and operates at higher temperatures which can result in premature engine maintenance. Importantly, every kilogram of fuel saved by an airline result in the elimination of 3.15 kilograms of carbon dioxide $\left(\mathrm{CO}_{2}\right)$ emissions (Air Transport Action Group, 2021b).

Singapore Airlines, for example, have introduced an aircraft fleet-wide engine washing program, which has delivered an annual saving in fuel savings of 10,400 tonnes of fuel savings annum (Singapore Airlines, 2017). In addition to the greater fuel efficiency, this initiative has resulted in lower annual carbon dioxide $\left(\mathrm{CO}_{2}\right)$ emissions of around 32,670 tonnes.

\subsection{Sustainable Air Freight Alliance}

Delta Cargo joined the Sustainable Air Freight Alliance (SAFA) in September 2020. The Sustainable Air Freight Alliance (SAFA) is a business-led collaborative initiative whose goal is to reduce its members' environmental footprint. SAFA is a collaboration between shippers, freight forwarders, and airlines to track and reduce emissions from air cargo transportation. The organization promotes responsible freight transport (Air Cargo News, 2020; Brown, 2020; Finn, 2020). SEKO Logistics joined the Sustainable Air Freight Alliance (SAFA) in March 2021 (Brett, 2021b; Seko Logistics, 2021). The membership of this organization was part of Seko Logistics goal to accelerate its global decarbonization program and help the company's clients to achieve their own sustainability goals. AirBridgeCargo Airlines, American Airlines, Cargolux, Cathay Pacific, Delta Air Lines, LOT Polish Airlines, Lufthansa Cargo, Polar Air Cargo, Scandinavian Airlines (SAS), and United Airlines are members the Sustainable Air Freight Alliance (SAFA) (Seko Logistics, 2021). Ceva Logistics, a global logistics service provider, is also a member of the Sustainable Air Freight Alliance (SAFA) (Ceva Logistics, 2021). Unique Logistics International has also joined the Sustainable Air Freight Alliance (Unique Logistics International, 2021).

\section{CONCLUSION}

Based on an in-depth qualitative instrumental case study research design, this study has examined the strategies and measures being adopted by the world's air cargo carrying airlines to decarbonize their operations, and thus, mitigate their impact on the environment. The study also examined the potential strategies and measures that the key industry stakeholders are considering as part of their decarbonization goals. The study covered the period 2004 to 2021 . The case study documentation was examined by document analysis. 
The case study found that the world's air cargo carrying airlines are very cognizant of their environmental impact and, as a result, air cargo carrying airlines have defined and implemented an extensive range of measures and strategies to decarbonize their operations. These measures include the acquisition and deployment of fuel-efficient next generation aircraft, such as the Airbus A350, Boeing 787 passenger aircraft and the Boeing B747-8 freighter aircraft, aircraft related carbon dioxide $\left(\mathrm{CO}_{2}\right)$ emissions offset programs, the use of fixed electrical ground power (FEGP) and pre-conditioned air at airports, the use of lightweight aircraft unit load devices (ULDs), use of sustainable aviation fuels, the use of renewable energy sources for ground based buildings and facilities, the electrification of air cargo carrying airlines ground service equipment (GSE), the optimization of air traffic management procedures, and the washing of aircraft engines. A further decarbonization strategy has been the membership of key industry bodies, such as, the Sustainable Air Freight Alliance. A key strategy adopted by the world's air cargo carrying airlines has been the use of sustainable aviation fuels (SAF). Sustainable aviation fuels (SAF) provide a very significant opportunity for the decarbonization of aircraft operations as these fuels can reduce carbon dioxide $\left(\mathrm{CO}_{2}\right)$ emissions by up to $80 \%$ over its full lifecycle.

The case study also revealed that several key air cargo industry actors are planning in the future to use electric powered aircraft. The potential use of hydrogen as an aircraft energy source is also being considered.

A byproduct of air cargo transportation is the significant production of wastes. To mitigate the environmental impact of these wastes, air cargo carrying airlines could consider adopting the circular economy waste management approach.

\section{REFERENCES}

[1] Abd, A.A., Othman, M.R., \& Kim, J. (2021). A review on application of activated carbons for carbon dioxide capture: present performance, preparation, and surface modification for further improvement. Environmental Science and Pollution Research, 28, 43329-43364. https://doi.org/10.1007/s11356-021-15121-9

[2] Abdullah, M.A., Chew, B.C., \& Hamid, S.R. (2016). Benchmarking key success factors for the future green airline industry. Procedia - Social and Behavioral Sciences, 224 , 246

253. https://doi.org/10.1016/j.sbspro.2016.05.456

[3] Ahmed, M., Ahmad, S., Tariq, M., Fatima, Z., Aslam, Z., Ali Raza, M., Iqbal, N., Akmal, M., Hassan, F.U., Akhtar Abbasi, N., \& Hayat, R. (2020). Wastes to be the source of nutrients and energy to mitigate climate change and ensure future sustainability: options and strategies. Journal of
Plant Nutrition, 43(6), 896-920. https://doi.org/10.1080/01904167.2020.1711944

[4] Airbus. (2018). Airbus delivers its first A350-1000 to launch customer Qatar Airways. Retrieved from https://www.airbus.com/en/newsroom/press-releases/201802-airbus-delivers-its-first-a350-1000-to-launch-customerqatar.

[5] Air Cargo News. (2013a). Alf helps Etihad cut costs. Retrieved from https://www.aircargonews.net/uncategorized/alf-helpsetihad-cut-costs/.

[6] Air Cargo News. (2013b). Swiss WorldCargo opts for lightweight ULDs. Retrieved from https://www.aircargonews.net/uncategorized/swissworldcargo-opts-for-lightweight-ulds/.

[7] Air Cargo News. (2015a). Cargolux opts for Telair lightweight ULDs. Retrieved from https://www.aircargonews.net/business/cargolux-opts-fortelair-lightweight-ulds/.

[8] Air Cargo News. (2015b). Cargo pallets go on a diet. Retrieved from https://www.aircargonews.net/business/cargo-pallets-goon-a-diet/.

[9] Air Cargo News. (2015c). Cathay and CHEP in ULD management deal. Retrieved from https://www.aircargonews.net/airlines/cathay-and-chep-inuld-management-deal/.

[10] Air Cargo News. (2015d). Lightweight ULDs to cut TAP's fuel bill. Retrieved from https://www.aircargonews.net/airlines/lightweight-ulds-tocut-taps-fuel-bill/.

[11] Air Cargo News. (2015e). Lufthansa launches flyweight LD3s. Retrieved from https://www.aircargonews.net/airlines/lufthansa-launchesflyweight-ld3s/.

[12] Air Cargo News. (2015f). United Cargo adopts lighter containers. Retrieved from https://www.aircargonews.net/technology/united-cargoadopts-lighter-containers/.

[13] Air Cargo News. (2015g). WCS: Jettainer's lightweight pallet. Retrieved from https://www.aircargonews.net/airlines/bellyholdairline/wcs-jettainers-lightweight-pallet/.

[14] Air Cargo News. (2016a). Alitalia opts for lightweight ULDs. Retrieved from https://www.aircargonews.net/airlines/alitalia-opts-forlightweight-ulds/.

[15] Air Cargo News. (2016b). Fiji Airways renews ULD contract with CHEP. Retrieved from https://www.aircargonews.net/airlines/fiji-airways-renewsuld-contract-with-chep/.

[16] Air Cargo News. (2016c). Norwegian opts for Zodiac on B787s. Retrieved from https://www.aircargonews.net/technology/norwegian-optsfor-zodiac-on-b787s/.

[17] Air Cargo News. (2016d). SAS opts for lightweight ULDs. Retrieved from 
https://www.aircargonews.net/region/europe/sas-opts-forlightweight-ulds/.

[18] Air Cargo News. (2020). SAFA grows. Air Cargo News, 886, 16.

[19] Air Cargo News. (2021a). DB teams with Lufthansa to cut the carbon. Air Cargo News, 893, 9.

[20] Air Cargo News. (2021b). Geodis goes SAF green. Air Cargo News, 895, 8.

[21] Air Cargo News. (2021c). Salmon by sea puts focus on CO2. Air Cargo News, 889, 15.

[22] Air Cargo Week. (2021). AFKLMP Cargo welcomes Koppert to its sustainable aviation fuel programme. Air Cargo Week, 1(129), 8.

[23] Air Cargo World. (2021). Rolls-Royce, Shell deepens sustainable jet-fuel partnership. Retrieved from https://aircargoworld.com/news/technology/rolls-royceshell-deepen-sustainable-jet-fuel-

partnership/?utm_source=ACW+Main+List\&utm_campaig $\mathrm{n}=\mathrm{c} 8 \mathrm{c} 4561 \mathrm{~b} 8 \mathrm{~b}-$

$\mathrm{ACW}+\mathrm{Technology}+$ Newsletter\&utm_medium=email\&utm _term=0_1711f92e66-c8c4561b8b-39015409.

[24] Aircraft Commerce. (2015). 787 \& A350 XWB: How do they reduce maintenance costs? Aircraft Commerce, 102, 16-23.

[25] Aircraft Commerce. (2016). Fuel burn \& operating performance of the 787-8, 787-9 and A350-900. Aircraft Commerce, 108, 16-27.

[26] Airline Ground Services. (2013). Containers can take the strain. Airline Ground Services, June, 20-23.

[27] Airline Routes and Ground Services. (2018). Containers can take the strain. Retrieved from https://airlinergs.com/issue-article/containers-can-take-thestrain/.

[28] Airport Technology. (2021). Boeing 747-8 Intercontinental airliner. Retrieved from https://www.aerospacetechnology.com/projects/boeing-747-8/.

[29] Airside International. (2012). Getting it right: Aircraft power on the stand. Airside International, 19, 23-25.

[30] Airside International. (2020). Electric tow tractors: Evidence of a long-term trend? Airside International, 51, 610 .

[31] Airside International. (2021). Aviaco GSE delivers electric baggage tractors into Schiphol. Airside International, 54, 26-27.

[32] Air Transport Action Group. (2021a). Boeing 747-8. Retrieved from https://aviationbenefits.org/casestudies/boeing-747-8/.

[33] Air Transport Action Group. (2021b). EcoPower engine wash. Retrieved from https://aviationbenefits.org/casestudies/ecopower-engine-wash.

[34] Albers, S. (2016). Cases on managing strategic alliances and networks. In J. Sydow, E. Schübler \& G. Müller-Seitz (Eds.), Managing interorganizational relationships: Debates and cases (pp. 57-100). London, UK: Macmillan Publishers Ltd.

[35] Alemán, M.A. (2010) International aviation security practices relating to the global supply chain. In A.R. Thomas (Ed.), International practices and innovations in moving goods safely and efficiently (pp. 189-197). Santa Barbara, CA: ABC-CLIO, LLC.

[36] Al Hajri, G. (1999). The impact of sea-air mode on air cargo transport. Merstham, UK: A-Z Group Limited.

[37] All Nippon Airways. (2021). ANA launches SAF flight initiative to promote sustainability and reduced $\mathrm{CO}_{2}$ emissions. $\quad$ Retrieved from https://www.anahd.co.jp/group/en/pr/202110/20211014.ht $\mathrm{ml}$.

[38] Arman, H., \& Yuksel, I. (2013). Preface. In H. Arman \& I. Yuksel (Eds.) New developments in renewable energy (pp. xi-xii). Rijeka, Croatia: InTech.

[39] Ashford, N.J., Stanton, H.P.M., Moore, C.A., Coutu, P., \& Beasley, J.R. (2013). Airport operations (3rd ed.). New York, NY: McGraw-Hill.

[40] Aviation Pros. (2012). Airberlin modernises container fleet. Retrieved from https://www.aviationpros.com/gse/baggagecargo/cargo-handling-equipment-accessories/uldcontainers/news/10756191/lightweight-containers-savefuel-and-cut-carbon-emissions.

[41] Awasthi, M.K., Sarsaiya, S., Chen, H., Wang, Q., Kumar Awasthi, S., Li, J., Liu, T., Pandey, A., \& Zhang, Z. (2019). Global status of waste-to-energy technology. In S. Kumar, R. Kumar \& A. Pandey (Eds), Current developments in biotechnology and bioengineering: Waste treatment processes for energy generation (pp. 31-52). Amsterdam, The Netherlands: Elsevier.

[42] Baroutaji, A., Wilberforce, T., Ramadan, M., \& Ghani Olabi, A. (2019). Comprehensive investigation on hydrogen and fuel cell technology in the aviation and aerospace sectors. Renewable and Sustainable Energy Reviews, 106, 31-40. https://doi.org/10.1016/j.rser.2019.02.022

[43] Bartsch, R.I.C. (2013). International aviation law: A practical guide. Farnham, UK: Ashgate Publishing.

[44] Bauen, A., \& Nattrass, L. (2018). Sustainable aviation biofuels: Scenarios for deployment. In M. Kaltschmitt \& U. Neuling (Eds.), Biokerosene: Status and prospects (pp. 703-721). Berlin, Germany: Springer-Verlag.

[45] Baxter, G. (2016). AERO2410 Airline operations: Topic 6 learning guide: Airline capacity management and passenger aircraft fleet planning. Melbourne: RMIT University.

[46] Baxter, G. (2020). Sustainable airline waste management: A case study of Air New Zealand's waste management programs and strategies. International Journal for Traffic and Transport Engineering, 10(3), 351-370.

[47] Baxter, G. (2021). Achieving carbon neutral airport operations by 2025: The case of Sydney Airport, Australia. Transport and Telecommunication, 22(1), 1-14. https://doi.org/10.2478/ttj-2021-0001

[48] Baxter, G., \& Wild, G. (2021). Aviation safety, freight, and dangerous goods transport by air. In R. Vickerman (Ed.), International encyclopedia of transportation (pp. 98-107). Amsterdam, The Netherlands: Elsevier.

[49] Baxter, G., Kourousis, K., \& Wild, G. (2014). Fire resistant aircraft unit load devices and fire containment covers: A new development in the global air cargo industry. Journal 
of Aerospace Technology and Management, 6(2), 202-209. https://doi.org/10.5028/jatm.v6i2.327

[50] Baxter, G., Srisaeng, P., \& Wild, G. (2018). An assessment of airport sustainability, Part 1-Waste management at Copenhagen Airport. Resources, 7(1), 21. https://doi.org/10.3390/resources7010021

[51] Baxter, G., Srisaeng P., \& Wild G. (2020). The use of aviation biofuels as an airport environmental sustainability measure: The case of Oslo Gardermoen Airport. Magazine of Aviation Development, 8(1), 6-17. https://doi.org/10.14311/MAD.2020.01.01

[52] Baxter, G., Srisaeng, P., \& Wild, G. (2021a). A qualitative assessment of a full-service network airline sustainable energy management: The case of Finnair PLC. WSEAS Transactions on Environment and Development, 17, 167180.

[53] Baxter, G., Srisaeng, P., \& Wild, G. (2021b). Environmentally sustainable airline waste management: The case of Finnair PLC. Environmental Research, Engineering and Management, 77(4), 73-85. https://doi.org/10.5755/j01.erem.77.4.29574

[54] Benito, A., \& Alonso, G. (2018). Energy efficiency in air transportation. Oxford, UK: Butterworth Heinemann.

[55] Beasley, K.T., \& Bernadowski, C. (2019). An examination of reading specialist candidates' knowledge and selfefficacy in behavior and classroom management: An instrumental case study. Education Sciences, 9(2), 76. https://doi.org/10.3390/educsci9020076

[56] Biofuels International. (2021a). AFKLMP welcomes Airpharm Logistics to its SAF programme. Retrieved from https://biofuels-news.com/news/afklmp-cargo-welcomestotal-touch-cargo-to-its-saf-programme/.

[57] Biofuels International. (2021b). AFKLMP Cargo welcomes Total Touch Cargo to its SAF programme. Retrieved from https://biofuels-news.com/news/afklmp-welcomesairpharm-logistics-to-its-saf-programme/.

[58] Bittner, A., Tyner, W.E., \& Zhao, X. (2015). Field to flight: A techno-economic analysis of the corn stover to aviation biofuels supply chain. Bio Fuels, Bio Products \& Biorefining, 9(2), 201-210 https://doi.org/10.1002/bbb.1536

[59] Blanca-Alcubilla, G., Roca, M., Bala, A., Sanz, N., De Castro, N., \& Fullana-i-Palmer, P. (2019). Airplane cabin waste characterization: Knowing the waste for sustainable management and future recommendations. Waste Management, $\quad 96, \quad 57-64$. https://doi.org/10.1016/j.wasman.2019.07.002

[60] Boeing Commercial Airplanes. (2014). Boeing 767-300F designed to deliver. Retrieved from https://www.boeing.com/farnborough2014/pdf/BCA/bck767_5_13_2014.pdf.

[61] Boeing Commercial Airplanes. (2020). World air cargo forecast: 2020-2039. Retrieved from https://www.boeing.com/resources/boeingdotcom/market/a ssets/downloads/2020_WACF_PDF_Download.pdf.

[62] Boeing Commercial Airplanes. (2021). Boeing freighter family. Retrieved https://www.boeing.com/commercial/freighters/\#/767fhighlight/767f/advantages/.

[63] Boon, T. (2020). Which airlines fly the Boeing 787-10? Retrieved from https://simpleflying.com/boeing-787-10airlines/.

[64] Brett, D. (2019). Jettainer teams up with trilatec on weightsaving tech. Retrieved from https://www.aircargonews.net/services/uld/jettainer-teamsup-with-trilatec-on-weight-saving-tech/.

[65] Brett, D. (2020). Air France KLM Cargo launches sustainable fuel programme. Retrieved from https://www.aircargonews.net/airlines/air-france-klmcargo-launches-sustainable-fuel-programme/.

[66] Brett, D. (2021a). Air cargo to lead aviation in carbon reduction. $\quad$ Retrieved from https://www.aircargonews.net/policy/environment/aircargo-to-lead-aviation-in-carbon-reduction/.

[67] Brett, D. (2021b). Air cargo sector continues sustainability push. Retrieved from https://www.aircargonews.net/airlines/air-cargo-sectorcontinues-sustainability-push/.

[68] Brett, D. (2021c). ASL to buy hydrogen conversion kits for ATRs. Retrieved from https://www.aircargonews.net/policy/environment/asl-tobuy-hydrogen-conversion-kits-for-atrs/.

[69] Brett, D. (2021d). Bolloré Logistics launches SAF programme. Retrieved from https://www.aircargonews.net/freight-forwarder/bollorelogistics-launches-saf-programme/.

[70] Brett, D. (2021e). DHL Global Forwarding signs up for United's SAF programme. Retrieved from https://www.aircargonews.net/policy/environment/dhlglobal-forwarding-signs-up-for-uniteds-saf-programme/.

[71] Brett, D. (2021f). K+N and Lufthansa Cargo partner on PTL aviation fuel. Retrieved from https://www.aircargonews.net/policy/environment/kn-andlufthansa-cargo-partner-on-ptl-aviation-fuel/.

[72] Brett, D. (2021g). Lufthansa Cargo offers CO2 'neutral' freight service. Retrieved from https://www.aircargonews.net/policy/environment/lufthansa -cargo-offers-co2-neutral-freight-service/.

[73] Brett, D. (2021h). Two more forwarders sign up for Air France KLM Cargo's SAF programme. Retrieved from https://www.aircargonews.net/policy/environment/twomore-forwarders-sign-up-for-air-france-klm-cargos-safprogramme/.

[74] Brown, A. (2020). Delta Cargo commits to more sustainable future. Retrieved from https://www.aircargoweek.com/delta-cargo-commits-tomore-sustainable-future/.

[75] Brown, J., \& Jackson, M. (2004). FedEx to build solar system at Oakland hub. Retrieved from https://www.bizjournals.com/memphis/stories/2004/10/18/ daily5.html.

[76] Budd, L., \& Ison, S. (2017). The role of dedicated freighter aircraft in the provision of global airfreight services. Journal of Air Transport Management, 61, 34-40. https://doi.org/10.1016/j.jairtraman.2016.06.003 
[77] Budd, L., Griggs, S., \& Howarth, D. (2013). Sustainable aviation futures: Crises, contested realities and prospects for change. In L. Budd, S. Griggs \& D. Howarth (Eds.), Sustainable aviation futures (pp. 3-36). Bingley, UK: Emerald Publishing.

[78] Budd, T. (2017). Environmental impacts and mitigation. In L. Budd \& S. Ison (Eds.), Air transport management: An international perspective (pp. 283-306). Abingdon, UK: Routledge.

[79] Burneo, D., Cansino, J.M, \& Yñiguez, R. (2020). Environmental and socioeconomic impacts of urban waste recycling as part of circular economy. The case of Cuenca (Ecuador). $\quad$ Sustainability, $12(8), \quad 3406$. https://doi.org/10.3390/su12083406

[80] Cargolux International Airlines. (2011) Annual report 2010. Cargolux International Airlines, Luxembourg.

[81] Cargolux International Airlines. (2019) Sustainability report 2018. Retrieved from https://www.cargolux.com/media-library/files/csr/csrreport-20182.

[82] Cargolux International Airlines. (2021). Cargolux launches SAF program. Retrieved from https://cargolux.com/mediaroom/media-releases/media-releases/Cargolux-launchesSAF-program.

[83] Ceva Logistics. (2021). Our climate goal. Retrieved from https://www.cevalogistics.com/en/who-weare/commitments/carbon-footprint.

[84] Chen, F.Y. (2012). Managers' views on environmental management: An examination of the Taiwanese airline industry. Journal of Sustainable Development, 6(1), 65-75.

[85] Chiambaretto, P., Mayenc, E., Chappert, H., Fernandez, A.S., \& Le Roy, F. (2021). Where does flygskam come from? The role of citizens' lack of knowledge of the environmental impact of air transport in explaining the development of flight shame. Journal of Air Transport Management, $\quad 93,102049$. https://doi.org/10.1016/j.jairtraman.2021.102049

[86] Conway, P. (2005). Decline of the jumbo? Airline Business, 21(4), 62-63.

[87] Conway, P. (2011). Lifting the load. Flight International, 179(5291), 34-36.

[88] Conway, P. (2012) Volume switch. Flight International, 181(5344), 28-29.

[89] Cortez, L.A.B. (2014). Roadmap for sustainable aviation biofuels for Brazil: A flightpath to aviation biofuels in Brazil. Sao Paulo, Brazil: Blucher, 2014.

[90] Cortez, L.A.B., Nigro, F.E.B, Nogueira, L.A.H., Nassar, A.M., Cantarella, H., Moraes, M.A.F.D., Leal, R.L.V, Franco, T.T., Schuchardt, U.F., \& Baldassin, R. Jnr. (2015). Perspectives for sustainable aviation biofuels in Brazil. International Journal of Aerospace Engineering, 2015, 264898. https://doi.org/10.1155/2015/264898

[91] Coyle, J.J., Novack, R.A., Gibson, B.J., \& Bardi, E.J. (2011). Transportation: A supply chain perspective (7th ed.). Mason, $\mathrm{OH}$ : South-Western Cengage Publishing

[92] Davies, H. (2013). Freighter conversions. Aircraft Technology, 126, 50-54.
[93] DB Schenker. (2021). DB Schenker, Lufthansa Cargo and Nokia join forces on CO2-neutral air freight. Retrieved from https://www.dbschenker.com/global/about/press/dbschenker-lufthansa-cargo-and-nokia-join-forces-739578.

[94] De Grosbois, D., \& Fennell, D. (2011). Carbon footprint of the global hotel companies: Comparison of methodologies and results. Tourism Recreation Research, 36(3), 231-245. https://doi.org/10.1080/02508281.2011.11081669

[95] Dempsey, P.S., \& Gesell, L.E. (1997). Air transportation: Foundations for the 21 st century. Chandler, AZ: Coast Aire Publications.

[96] de Neufville, R., \& Odoni, A. (2013). Airport systems: Planning, design, and management (2nd ed.). New York, NY: McGraw-Hill.

[97] Dewulf, W., Meersman, H., \& Van de Voorde, E. (2019). The strategy of air cargo operators: Carpet sellers and cargo stars. In K. Cullinane (Ed.). Airline economics in Europe (167-200). Bingley, UK: Emerald Publishing.

[98] DHL Group. (2021). DHL Express shapes future for sustainable aviation with the order of first-ever all-electric cargo planes from Eviation. Retrieved from https://www.dhl.com/global-en/home/press/pressarchive/2021/dhl-express-shapes-future-for-sustainableaviation-with-the-order-of-first-ever-all-electric-cargoplanes-from-eviation.html.

[99] Dodd, T., Orlitzky, M., \& Nelson, T. (2018). What stalls a renewable energy industry? Industry outlook of the aviation biofuels industry in Australia, Germany, and the USA. Energy Policy, 123, 92-103. https://doi.org/10.1016/j.enpol.2018.08.048

[100] Doganis, R. (2019). Flying off course: Airline economics and marketing (4th ed.). Abingdon, UK: Routledge.

[101] Dresner, M., \& Zou, L. (2017). Air cargo and logistics. In L. Budd \& S. Ison (Eds), Air transport management: An international perspective (pp. 247-264). Abingdon, UK: Routledge.

[102] Elmer, V., Leigland, A. (2014). Infrastructure planning and finance: A smart and sustainable guide. London, UK: Routledge.

[103] Emirates Airline. (2021). Environment: Sustainability in operations. Retrieved from https://www.emirates.com/au/english/about-us/ourplanet/sustainability-in-operations/.

[104] European Commission. (2021). Reducing emissions from aviation. Retrieved from https://ec.europa.eu/clima/policies/transport/aviation_en.

[105] European Environment Agency. (2016). Circular economy to have considerable benefits, but challenges remain. Retrieved from https://www.eea.europa.eu/highlights/circular-economy-tohave-considerable.

[106] Eurostat. (2020). Greenhouse gas emissions from waste. Retrieved from https://ec.europa.eu/eurostat/web/productseurostat-news/-/DDN-20200123-1.

[107] Fatihah, S., \& Abdul Rahim, A.S. (2017). The willingness to pay of air travel passengers to offset their carbon dioxide $\left(\mathrm{CO}_{2}\right)$ emissions: A Putrajaya resident case study. Journal 
of Tourism, Hospitality and Environment Management, 2(5), 18-32.

[108] FedEx. (2010). FedEx inaugurates new solar-powered hub at Cologne Bonn Airport. Retrieved from https://newsroom.fedex.com/newsroom/fedex-inauguratesnew-solar-powered-hub-at-cologne-bonn-airport/.

[109] FedEx. (2012). FedEx Express breaks ground on new solar installation at Newark hub facility. Retrieved from https://newsroom.fedex.com/newsroom/fedex-expressbreaks-ground-on-new-solar-installation-at-newark-hubfacility/.

[110] Finn, R. (2020). Delta Cargo commits to sustainable future. Retrieved from https://www.airfreight-logistics.com/deltacargo-commits-to-more-sustainable-future/.

[111] Finn, R. (2021). AFKLMP Cargo and Bolloré Logistics team up under SAF program. Retrieved from https://www.airfreight-logistics.com/afklmp-cargo-andbollore-logistics-team-up-under-saf-program/.

[112] Finnair. (2019). Sustainability report 2018. Retrieved from https.//company.finnair.com/ /media/Files/F/Finnair-

IR/documents/en/.../Finnair-sustainability-report-2018.pdf,

[113] Finnair. (2020). Sustainability report 2019. Retrieved from https.//company.finnair.com/resource/blob/1994132/c49368 6a5af678b81ed6dbcd48eed150/fiinair-responsibility-report2019-data.pdf

[114] Franchetti, M.J., \& Apul, D. (2013). Carbon footprint analysis: Concepts, methods, implementation, and case studies. Boca Raton: CRC Press.

[115] Fregnani, A.T.G., \& Andrade, O. (2017). Aviation initiatives and the relative impact of electric road vehicles on $\mathrm{CO}_{2}$ emissions. Retrieved from https://www.boeing.com/resources/boeingdotcom/features/i nnovationquarterly/aug2017/BTJ_CO2emissions_FULL.pdf.

[116] Fried, B. (2021). How air cargo is responding to climate change. $\quad$ Retrieved from https://www.aircargonews.net/freight-forwarder/how-aircargo-is-responding-to-climate-change/.

[117] Gautam, M., Pandey, B. \& Agrawal, M. (2012). Carbon footprint of aluminum production: Emissions and mitigation. In S. S. Muthu (Ed.), Environmental carbon footprints: Industrial case studies (pp. 197-228). Oxford, UK: Butterworth-Heinmann.

[118] Gegg, P., Budd, L., \& Ison, S. (2014). The market development of aviation biofuel: Drivers and constraints. Journal of Air Transport Management, 39, 34-40. https://doi.org/10.1016/j.jairtraman.2014.03.003

[119] Gellings, C.W. (2011). Saving energy and reducing $\mathrm{CO}_{2}$ emissions with electricity. Lilburn, GA: The Fairmont Press.

[120] Ghosh, S.K. (2020). Introduction to circular economy and summary analysis of chapters. In S.K. Ghosh (Ed.), Circular economy: Global perspective (pp. 1-23). Singapore: Springer Nature Singapore.

[121] Ginga, C.P., Ongpeng, M.C., \& Klarissa Daly, M. (2020). Circular economy on construction and demolition waste: A literature review on material recovery and production.
Materials,

13(13),

2970.

https://doi.org/10.3390/ma13132970

[122] Global Cargo Insight. (2021). Bolloré joins AFKLMP's SAF programme. Retrieved from https://www.globalcargoinsight.com/bollore-joins-afklmpssaf-programme.

[123] Golmohammad, F., \& Mehdizadeh Dastjerdi, A. (2012) The economic analysis of satellite-based CNS/ATM in Iranian air transportation. In R. Curran, L. Fischer, D. Pérez, K. Klein, J. Hoekstra, P. Roling \& W.J.C. Verhagen (Eds.), Air transport and operations: Proceedings of the Third International Air Transport and Operations Symposium 2012 (pp. 540-551). Amsterdam, The Netherlands: IOS Press BV.

[124] Gössling, S., \& Upham, P. (2009). Introduction: Aviation and climate change in context. In S. Gössling \& P. Upham (Eds.), Climate change and aviation: Issues, challenges, and solutions (pp. 1-23). London, UK: Earthscan.

[125] Graham, J. (2021a). First Asia operation joins AFKLMP Cargo SAF programme. Retrieved from https://www.aircargoweek.com/first-asia-operation-joinsafklmp-cargo-saf-programme/?mc_cid=959b1f51df.

[126] Graham, J. (2021b). ACL Airshop: Focused on growth. Retrieved from https://www.aircargoweek.com/acl-airshopfocused-on-growth/?mc_cid=5841 $12 \mathrm{e} 69$.

[127] Grandy, G. (2010). Instrumental case study. In A.J. Mills., G. Durepos \& E. Wiebe (Eds.), Encyclopedia of case study research, Volume 1 (pp. 473-475). Thousand Oaks, CA: SAGE Publications.

[128] Grasso Macola, I. (2021). DHL bets on electric cargo planes to deliver on zero emissions, Retrieved from https://www.airport-technology.com/features/dhl-bets-onelectric-cargo-planes-deliver-on-zero-emissions/.

[129] Grover, D. (2021). Kuehne+Nagel launch first carbon neutral air freight lane with Air France KLM Cargo. Retrieved from https://cargonewswire.com/kuehnenagellaunch-first-carbon-neutral-air-freight-lane-with-air-franceklm-cargo/.

[130] Harper, M. (2004). Introduction. In M. Ali (Ed.), Sustainable composting: Case studies and guidelines for developing countries (pp. 3-4). Loughborough, UK: Water, Engineering and Development Centre.

[131] Harry, R. (2020a). Lufthansa Cargo and DB Schenker operate first CO2-neutral freighter flights. Retrieved from https://www.aircargonews.net/policy/environment/lufthansa -cargo-and-db-schenker-partner-to-operate-co2-neutralfreighter-flights/.

[132] Harry, R. (2020b). Shell to supply SAF to DHL Express at Schiphol. Retrieved from https://www.aircargonews.net/sectors/energylogistics/shell-to-supply-saf-to-dhl-express-at-schiphol/.

[133] Harry, R. (2021a). AFKLMP Cargo welcomes five East Asian companies to its SAF Programme. Retrieved from https://www.aircargonews.net/policy/environment/afklmpcargo-welcomes-five-east-asian-companies-to-its-safprogramme/.

[134] Harry, R. (2021b). DB Schenker and Lufthansa launch Frankfurt-Shanghai $\mathrm{CO}_{2}$-neutral freighter route. Retrieved 
from https://www.aircargonews.net/policy/environment/dbschenker-and-lufthansa-launch-frankfurt-shanghai-co2neutral-freighter-route/.

[135] Harry, R. (2021c). CEVA Logistics joins United's sustainability initiative. Retrieved from https://www.aircargonews.net/policy/environment/cevalogistics-joins-uniteds-sustainability-initiative/.

[136] Harry, R. (2021d). Geodis the latest firm to offer SAFpowered flights for airfreight. Retrieved from https://www.aircargonews.net/policy/environment/geodisthe-latest-firm-to-offer-saf-powered-flights-for-airfreight/.

[137] Harry, R. (2021e). IAG Cargo and AFKLM partner with forwarders on SAF flights. Retrieved from https://www.aircargonews.net/airlines/iag-cargo-and-afklmpartner-with-forwarders-on-saf-flights/.

[138] Harry, R. (2021f). K+N and American partner to deploy $11 \mathrm{~m}$ litres of SAF. Retrieved from https://www.aircargonews.net/airlines/kn-and-americanpartner-to-deploy-11m-litres-of-saf/.

[139] Heng, Y.K. (2016). Managing global risks in the urban age: Singapore and the making of a global city. Abingdon, UK: Routledge.

[140] Hettiarachchi, H., \& Kshourad, C. (2019). Promoting waste-to-energy: nexus thinking, policy instruments, and implications for the environment. In S. Kumar, R. Kumar \& A. Pandey (Eds.), Current developments in biotechnology and bioengineering: Waste treatment processes for energy generation (pp. 163-184). Amsterdam, The Netherlands: Elsevier.

[141] Holland, F. (2021). DHL Express buys electric cargo planes for U.S. package delivery from start-up Eviation. Retrieved from https://www.cnbc.com/2021/08/03/dhl-express-buyseviation-electric-planes-for-us-package-delivery.html.

[142] Holland, J. (2021). Samad starts certification process of fully electric VTOL Starling Cargo aircraft. Retrieved from https://www.aviationbusinessnews.com/cargo/samad-startscertification-process-of-fully-electric-vtol-starling-cargoaircraft/.

[143] Honeycutt, K.J., \& Miller, D.R. (2021). Learner metacognitive insights from writing professional clinical practicum reflections: An instrumental case study of a University-Based MLS Program. Journal of Allied Health, 50(1), 67-72.

[144] Hrasky, S. (2012). Carbon footprints and legitimation strategies: Symbolism or action? Accounting, Auditing \& Accountability Journal, 25(1), 174-198. https://doi.org/10.1108/09513571211191798

[145] Hui, G.W.L., Hui, Y.V., \& Zhang, A. (2004). Analysing China's air cargo flows and data. Journal of Air Transport Management, $10(2), 125-135$ https://doi.org/10.1016/j.jairtraman.2003.08.003

[146] Humphries, M. (2021). UPS orders 10 electric aircraft for deliveries. $\quad$ Retrieved from https://au.pcmag.com/news/86509/ups-orders-10-electricaircraft-for-deliveries.

[147] Hunter, N. (2014). How carbon footprints work. New York, NY: Gareth Stevens Publishing
[148] Ierovante, M., Somersalo, F., \& Barth, A. (2015). ID for the freighter. Airbus Technical Magazine, October, 26-31.

[149] International Air Transport Association. (2021a). Developing sustainable aviation fuel (SAF). Retrieved from https://www.iata.org/en/programs/environment/sustainableaviation-fuels/.

[150] International Air Transport Association. (2021b). Offsetting $\mathrm{CO}_{2}$ emissions with CORSIA. Retrieved from https://www.iata.org/en/programs/environment/corsia/.

[151] International Airport Review. (2010). UK Airport operators launch new guidelines to reduce aircraft ground emissions. Retrieved from http://www.internationalairportreview.com/2717/airportnews/uk-airport-operators-launch-new-guidelines-toreduce-aircraft-ground-emissions/.

[152] International Civil Aviation Organization. (2012). Annual Report of the Council - 2011, Document 9975. Retrieved from https://www.icao.int/publications/Documents/9975_en.pdf.

[153] International Civil Aviation Organization. (2013). Annual Report of the Council - 2012, Document 10001 Retrieved from https://www.icao.int/publications/Documents/10001_en.pdf

[154] International Civil Aviation Organization. (2020). Presentation of 2019 air transport statistical results. Retrieved from https://www.icao.int/annual-report2019/Documents/ARC_2019_Air\%20Transport\%20Statisti cs.pdf.

[155] International Civil Aviation Organization. (2021). Waste management at airports. Retrieved from https://www.icao.int/environmentalprotection/documents/waste_management_at_airports_boo klet.pdf.

[156] International Coordinating Council of Aerospace Industries Associations. (2019). Advancing technology opportunities to further reduce $\mathrm{CO}_{2}$ emissions. Retrieved from https://www.icao.int/environmental-

protection/Documents/EnvironmentalReports/2019/ENVRe port2019_pg116-121.pdf.

[157] Itoh, E., \& Uejima, K. (2013). Applying flight-deck interval management based continuous descent operation for arrival air traffic to Tokyo International Airport. In: Proceedings of Tenth USA/Europe Air Traffic Management Research and Development Seminar (ATM 2013), June 1013, 2013, Chicago (pp. 1-10).

[158] Jackson, M. (2008). FedEx building German solar facility. Retrieved from https://www.icao.int/environmentalprotection/Documents/EnvironmentalReports/2019/ENVRe port2019_pg116-

121.pdfhttps://www.bizjournals.com/memphis/stories/2008 /10/20/daily1.html.

[159] Janić, M. (2011). Greening airports: Advanced technology and operations. London, UK: Springer-Verlag.

[160] Janić, M. (2016). The sustainability of air transportation: A quantitative analysis and assessment. Abingdon, UK: Routledge. 
[161] Japan Airlines. (2014). JAL introduces new light-weight cargo container on its international routes. Retrieved from http://press.jal.co.jp/en/bw_uploads/20140507-

JAL $\% 20$ Introduces $\% 20 \mathrm{New} \% 20$ lightweight $\% 20$ Cargo $\% 20$ Container $\% 20 \mathrm{on} \% 20$ its $\% 20$ Internati onal\%20Routes.pdf.

[162] Javed, T., Ahmed, A., Raman, V., Alqualty, A.B.S., \& Johansson, B. (2019). Combustion-based transportation in a carbon constrained world - A review. In R.A. Agarwal., A.K. Agarwal., T. Gupta \& N. Sharma (Eds.), Pollutants from Energy Sources: Characterization and Control (pp. 734). Singapore: Springer Nature Singapore.

[163] Kazda, A., \& Caves, R.E. (2015). Airport design and operation (3rd ed.). Bingley, UK: Emerald Group Publishing.

[164] Keen, G. (2021). Air France KLM Martinair Cargo welcomes Airflo and Tiger Freight to its Sustainable Aviation Fuel programme. Retrieved from https://www.caasint.com/air-france-klm-martinair-cargowelcomes-airflo-and-tiger-freight-to-its-sustainableaviation-fuel-programme/.

[165] Khandelwal, B., Karakurt, A., Sekaran, P.R., Sethi, V., \& Singh, R. (2013). Hydrogen powered aircraft: The future of air transport. Progress in Aerospace Sciences, 60, 45-59. https://doi.org/10.1016/j.paerosci.2012.12.002

[166] Kingsley-Jones, M. (2006). Airbus closes in on A330F launch. Flight International, 169(5042), 11.

[167] Kingsley-Jones, M. (2010) Worth the weight. Flight International, 177(5241), 29-33.

[168] Koppert Biological Systems. (2021). Air France KLM Martinair welcomes Koppert Biological Systems to its Sustainable Aviation Fuel programme. Retrieved from https://www.koppert.com/news/2021/air-france-klmmartinair-welcomes-koppert-biological-systems-to-itssustainable-aviation-fuel-programme/.

[169] Kováčik, L., Lusiak, L. \& Novák, A. (2021). Reducing emissions from aviation and their impact on aviation work in agriculture. Transportation Research Procedia, 55, 220 227. https://doi.org/10.1016/j.trpro.2021.06.025

[170] Kyriakopoulos, G.L., Kapsalis, V.C, Aravossis, K.G., Zamparas, M., \& Mitsikas, A. (2019). Evaluating circular economy under a multi-parametric approach: A technological review. Sustainability, 11(21), 6139. https://doi.org/10.3390/su11216139

[171] Laniel, M., Uysal, J., \& Emond, J. P. (2011). Radio frequency interactions with air cargo container materials for real-time cold chain monitoring. Applied Engineering in Agriculture, 27(4), 647-652.

[172] Lee, D. (2013). Meet the new FedEx efficient containers. Lighter design. less fuel. Retrieved from https://www.3blmedia.com/news/meet-new-fedex-efficientcontainers-lighter-design-less-fuel.

[173] Li, X.D., Poon, C.S., Lee, S.C., Chung, S.S., \& Luk, F. (2003). Waste reduction and recycling strategies for the inflight services in the airline industry. Resources, Conservation and Recycling, 37(3),87-99. https://doi.org/10.1016/S0921-3449(02)00074-5
[174] Longo, M., Lutz, N. M., Daniel, L. Zaninelli, D., \& Pruckner, M. (2017). Towards an impact study of electric vehicles on the Italian electric power system using simulation techniques. In Proceedings of the 2017 IEEE 3 rd International Forum on Research and Technologies for Society and Industry (RTSI), 2017 (pp. 1-5). 10.1109/RTSI.2017.8065911.

[175] Lu, H.A., \& Chen, C.Y. (2011). A time-space network model for unit load device stock planning in international airline services. Journal of Air Transport Management, $17(2)$, 94-100. https://doi.org/10.1016/j.jairtraman.2010.09.004

[176] Lu, H.A., \& Chen, C.Y. (2012). Safety stock estimation of unit load devices for international airline operations. Journal of Marine Science and Technology, 20(4), 431440.

[177] Macário, R., \& Van de Voorde, E. (2011). Introduction. In R. Macário \& E. Van de Voorde (Eds.), Critical issues in air transport economics and business (pp. 1-9). Abingdon, UK: Routledge.

[178] Maertens, S., Grimme, W., Scheelhaase, J., \& Jung, M. (2019). Options to continue the EU ETS for aviation in a CORSIA-world. Sustainability, 11(20), 5703. https://doi.org/10.3390/su11205703

[179] Manahan, S.E. (20110. Fundamentals of environmental chemistry (3rd ed.). Boca Raton, FL: CRC Press.

[180] Marais, K., Wolfe, P.J., \& Waitz, I.A. (2016). Air transport and the environment. In P. Belobaba, A. Odoni \& C. Barnhart (Eds), The global airline industry (pp. 423-457) (2nd ed.). Chichester, UK; John Wiley \& Sons.

[181] Marinetrans. (2021). Marinetrans (MT) has joined the Sustainable Aviation Fuel (SAF) programme of Air France KLM Martinair Cargo. Retrieved from https://marinetrans.com/newsroom/marinetrans-mt-hasjoined-the-sustainable-aviation-fuel-saf-program-of-airfrance-klm-martinair-cargo/.

[182] Masiol, M., \& Harrison, R.M. (2014). Aircraft engine exhaust emissions and other airport-related contributions to ambient air pollution: A review. Atmospheric Environment, 95 , 409-455. https://doi.org/10.1016/j.atmosenv.2014.05.070

[183] Mayer, R., Ryley, T., \& Gillingwater, D. (2012). Passenger perceptions of the green image associated with airlines. Journal of Transport Geography, 22, 179-186. https://doi.org/10.1016/j.jtrangeo.2012.01.007

[184] Merkert, R., \& Alexander, D. (2018). The air cargo industry. In N. Halpern \& A. Graham (Eds.), The Routledge companion to air transport management (pp. 29-47). Abingdon, UK: Routledge.

[185] Migdadi, Y.K.A.A. (2018). Identifying the best practices of airlines' green operations strategy: A cross-regional worldwide survey. Environmental Quality Management, 28(1), 21-32. https://doi.org/10.1002/tqem.21575

[186] Morrell, P.S. (2016). The air cargo industry. In J.F. O'Connell \& G. Williams (Eds.), Air transport in the 21st century: Key strategic developments (pp. 235-252). Abingdon, UK: Routledge. 
[187] Morrell, P.S., \& Klein, T. (2018). Moving boxes by air: The economics of international air cargo (2nd ed.). Abingdon, UK: Routledge.

[188] Nordisk Aviation Products. (2014). Nordisk completes delivery of 4,300 lightweight containers to Singapore Airlines. Retrieved from https://www.nordiskaviation.com/en/news/nordisk-completes-delivery-of-4300lightweight-containers-to-singapore-airlines/.

[189] Norris, G. (2006), Kings of cargo. Flight International, 169(5036), 36-38.

[190] Oates, B.J. (2006). Researching information systems and computing. London, UK: SAGE Publications.

[191] O'Leary, Z. (2004). The essential guide to doing research. London, UK: SAGE Publications.

[192] Ostrower, J. (2008). Green and versatile. Flight International, 174(5146), 46-50.

[193] Palmer, W. (2020). Sustaining flight: Comprehension, assessment, and certification of sustainability in aviation. In T. Walker, A.S. Bergantino, N. Sprung-Much \& L. Loiacono (Eds.), Sustainable aviation: Greening the flight path (pp. 7-28). Cham, Switzerland: Springer Nature Switzerland.

[194] Pitt, M., \& Smith, A. (2003). Waste management efficiency at UK airports. Journal of Air Transport Management, 9(2), 103-111. https://doi.org/10.1016/S0969-6997(02)00063-7

[195] Prosperi, D.C. (2009). Greening the world's airports. World Transport Policy \& Practice, 14(4), 48-56.

[196] Putzger, I. (2015). Air cargo still waits for the breakthrough: Lightweight pallets that don't break easy. Retrieved from https://theloadstar.com/air-cargo-still-waitsfor-the-breakthrough-lightweight-pallets-that-dont-breakeasy/.

[197] Rahman, M., Pudasainee, P., \& Gupta, R. (2017). Urban waste (municipal solid waste-MSW) to energy. In S. Devasahayam., K Dowling \& M.K. Mahapatra (Eds.), Sustainability in the mineral and energy sectors (pp.499530). Boca Raton: CRC Press.

[198] Ramachandra, T.V., \& Mahapatra, D.M. (2016). The science of carbon footprint assessment. In S.S. Muthu (Ed.), The carbon footprint handbook (pp. 4-44). Boca Raton, FL: CRC Press.

[199] Ramon Gil-Garcia, J. (2012). Enacting electronic government success: An integrative study of governmentwide websites, organizational capabilities, and institutions. New York, NY: Springer Science+Business Media.

[200] Ramsay, M. (2020). Loaders go electric. Airside International, 49, 8-11.

[201] Rand, T., Haukohl, J., \& Marxen, U. (2000). Municipal solid waste incineration: Requirements for a successful project. Washington, DC: The World Bank.

[202] Randall, C. (2019). Stuttgart airport expands electric cargo tractor fleet. Retrieved from https://www.electrive.com/2019/10/30/stuttgart-airportexpands-electric-cargo-tractor-fleet/.

[203] Reichmann, K. (2021a). Sustainable aviation fuels aren't sustainable, not yet at least. Retrieved from https://www.aviationtoday.com/2021/08/05/sustainableaviation-fuels-arent-sustainable-not-yet-least/.
[204] Reichmann, K. (2021b). UPS purchases Beta's eVTOL aircraft. Retrieved from https://www.aviationtoday.com/2021/04/09/ups-purchasesbetas-evtol-aircraft/.

[205] Rimoczi, R. (2020). Air France KLM, Martinair introduce 'Cargo SAF' fuel program. Retrieved from https://airwaysmag.com/airlines/af-kl-ma-cargo-saf-fuelprog/.

[206] Rondinelli, S., Gardi, A., Kapoor, R., \& Sabatini, R. (2017). Benefits and challenges of liquid hydrogen fuels in commercial aviation. International Journal of Sustainable Aviation, 3(3), 200-216.

[207] Sadang, J.M., Palompon, D.R., \& Suksatan, W. (2021). Older adults' experiences and adaptation strategies during the midst of COVID-19 crisis: A qualitative instrumental case study. Annals of Geriatric Medicine and Research, 25(2):

113-121. https://dx.doi.org/10.4235\%2Fagmr.21.0051

[208] Sales, M. (2013). The air logistics handbook: Air freight and the global supply chain. Abingdon, UK: Routledge.

[209] Sales, M. (2016). Aviation logistics: The dynamic partnership of air freight and supply chain. London, UK: Kogan Page.

[210] Sales, M. (2017). Air cargo management: Air freight and the global supply chain (2nd. ed.). Abingdon, UK: Routledge.

[211] Salmi, H. (2019). Light-weight ULDs and other energysaving gains by Finnair Cargo. Retrieved from https://cargo.finnair.com/en/cargo-news/light-weight-uldsand-other-energy-saving-gains-by-finnair-cargo-1764834.

[212] Salvatore, D. (2020). International economics (13th ed). Hoboken, NJ: John Wiley \& Sons.

[213] Sarkar, A. N. (2012). Evolving green aviation transport system: A Holistic approach to sustainable green market development. American Journal of Climate Change, 1, 164-180.

[214] Saunders, E. (2021a). AFKLMP Cargo adds five Chinese partners to its SAF Programme. Retrieved from https://www.caasint.com/afklmp-cargo-adds-five-chinesepartners-to-its-saf-programme/.

[215] Saunders, E. (2021b). AFKLMP Cargo welcomes Total Touch Cargo. Retrieved from https://www.caasint.com/afklmp-cargo-welcomes-totaltouch-cargo/.

[216] Saunders, E. (2021c). Cargolux launches SAF program. Retrieved from https://www.caasint.com/cargoluxlaunches-saf-program/.

[217] Schäfer, A.W. (2016). The prospects for biofuels in aviation. In C. Chuck (Ed.), Biofuels for aviation: Feedstocks, technology and implementation (pp. 3-16). London, UK: Academic Press.

[218] Scheelhaase, J., Maertens, S., \& Grimme, W. (2019). Synthetic fuels in aviation - Current barriers and potential political measures. Transportation Research Procedia, 43, 21-30. https://doi.org/10.1016/j.trpro.2019.12.015

[219] Schutte, J.S., Payan, AP., Briceno, S.I., \& Mavris, D.N. (2016). Hydrogen-powered aircraft. In R. Agarwal., F. 
Collier., A. Schäfer \& A. Seabridge. Green aviation (pp. 165-176). Chichester: John Wiley \& Sons.

[220] Scott, B.J. \& Trimarchi, A. (2020). Fundamentals of international aviation law and policy. Abingdon, UK: Routledge.

[221] Scott, J. (2014). A dictionary of sociology (4th ed.). Oxford, UK: Oxford University Press.

[222] Scott, J., \& Marshall, G. (2009). A dictionary of sociology (3rd ed.). Oxford, UK: Oxford University Press.

[223] Seko Logistics. (2021). Seko Logistics joins the Sustainable Air Freight Alliance. Retrieved from https://www.sekologistics.com/us/news/posts/2021/march/s eko-logistics-joins-the-sustainable-air-freight-alliance/.

[224] Shah, Y.T. (2021). Hybrid energy systems: Strategy for industrial decarbonization. Boca Raton, FL: CRC Press.

[225] Singapore Airlines. (2017). Sustainability report 2016/17. Retrieved

from https://www.singaporeair.com/saar5/pdf/InvestorRelations/Annual-Report/sustainabilityreport1617.pdf.

[226] Singapore Airlines. (2018). Sustainability report 2017/18. Retrieved from https://www.singaporeair.com/saar5/pdf/InvestorRelations/Annual-Report/sustainabilityreport1718.pdf.

[227] Singapore Airlines. (2020). Sustainability report 2019/20. Retrieved from https://www.singaporeair.com/saar5/pdf/InvestorRelations/Annual-Report/sustainabilityreport1920.pdf.

[228] Singapore Airlines. (2021). When it comes to carbonneutrality, we're not sitting on the fence. Retrieved from https://www.singaporeair.com/en_UK/gb/flyingwithus/our-story/giving-back/environmental-efforts/.

[229] Singh, J., Sharma-Kumar, S., \& Srivastava R. (2018). Managing fuel efficiency in the aviation sector: challenges, accomplishments and opportunities. FIIB Business Review, $7(4)$, 244-251. https://doi.org/10.1177\%2F2319714518814073

[230] Spellman, F.R. (2015). Environmental impacts of renewable energy. Boca Raton, FL: CRC Press.

[231] Sreeneth, S., Sudhakar, K., \& Yusop, A.F. (2021). Suitability analysis of solar tracking PV system in the airport based on glare assessment. International Journal of Automotive and Mechanical Engineering, 18(1), 90619070.

[232] Stake, R.E. (1995). The art of case study research. Thousand Oaks, CA: SAGE Publications.

[233] Stake, R.E. (2005). Qualitative case studies. In N.K. Denzin \& Y.S. Lincoln (Eds.), The SAGE handbook of qualitative research (pp. 443-466). Thousand Oaks, CA: SAGE Publications.

[234] Staples, M.D., Malina, R., Suresh, P., Hileman, J.I., \& Barrett, S.R.H. (2014). Aviation $\mathrm{CO}_{2}$ emissions reductions from the use of alternative jet fuels. Energy Policy, 114, 342-354. https://doi.org/10.1016/j.enpol.2017.12.007

[235] Su, Y., Zhang, P., \& Su, Y. (2015). An overview of biofuels policies and industrialization in the major biofuel producing countries. Renewable and Sustainable Energy Reviews, 50, 991-1003. https://doi.org/10.1016/j.rser.2015.04.032
[236] Szymczak, R. (2021). Assessing the impact of a potential short-haul flights ban on European airports. In A. Kwasiborska, J. Skorupski \& I. Yatskiv (Eds.), Advances in air traffic engineering, selected papers from 6th international scientific conference on air traffic engineering, ATE 2020, October 2020, Warsaw, Poland (pp. 146-163). Cham: Springer Nature Switzerland.

[237] Taiwo, A.M. (20110. Composting as a sustainable waste management technique in developing countries. Journal of Environmental Science and Technology, 4(2), 93-102.

[238] Tavares Kennedy, H. (2019). Finnair introduces $\mathrm{CO}_{2}$ offsetting and biofuel service for customers. Retrieved from https://www.biofuelsdigest.com/bdigest/2019/01/19/finnair -introduces-co2-offsetting-and-biofuel-service-forcustomers/.

[239] Teoh, L.E., \& Khoo H.L (2016). Green air transport system: An overview of issues, strategies and challenges. KSCE Journal of Civil Engineering, 20(3), 1040-1052. https://doi.org/10.1007/s12205-016-1670-3

[240] Thompson, B. (2007). Ground handling opportunities for airports. Journal of Airport Management, 1(4), 393-397.

[241] Times Aerospace (2012). Etihad introduces lightweight cargo containers. Retrieved from https://www.timesaerospace.aero/news/air-transport/etihadintroduces-lightweight-cargo-containers.

[242] Times Aerospace. (2021). AFKLMP Cargo welcomes Hellmann Worldwide Logistics to its SAF programme. Retrieved from https://www.timesaerospace.aero/news/maintenance/afklmp -cargo-welcomes-hellmann-worldwide-logistics-to-its-safprogramme.

[243] Trabold, T.A., \& Nair, V. (2019). Conventional food waste management methods. In T. Trabold \& C.W. Babbitt (Eds.), Sustainable food waste-to-energy systems (pp. 2945). London, UK: Academic Press.

[244] Tretheway, M.W., \& Andriulaitis, R.J. (2016). Airport competition for freight. In P. Forsyth., D. Gillen., J. Müllen \& H.M. Niemeier (Eds.), Airport competition: The European experience (pp. 137-150). Abingdon, UK: Routledge.

[245] Tuladhar, S., Ratna Bajracharyaa, T., \& Raj Shakyaa, S. (2021). Evaluation and mitigation analysis of carbon footprint for an airline operator: Case of Nepal Airlines Corporation. Journal of Innovation in Engineering Education, 4(1), 18-33.

[246] Turner, Y. (2020). AFKLMP Cargo launch SAF programme for airfreight. Retrieved from https://www.aircargoweek.com/afklm-martinair-cargolaunch-saf-programme-for-airfreight/.

[247] Turner, Y. (2021a). Airflo and Tiger Freight join AFKLMP's SAF programme. Retrieved from https://www.aircargoweek.com/airflo-and-tiger-freightjoin-afklmps-saf-programme/.

[248] Turner, Y. (2021b). ANA launches SAF Initiative. Retrieved from https://www.aircargoweek.com/analaunches-saf-initiative/?mc_cid=edc4d6dfb8.

[249] Turner, C. (2021c). Kuehne+Nagel to offer SAF option for all shipments. $\quad$ Retrieved from 
https://www.aircargoweek.com/kuehnenagel-to-offer-safoption-for-all-shipments/.

[250] Turner, Y. (2021d). More join AFKLMP SAF programme. Retrieved from https://www.aircargoweek.com/samadstarts-to-certify-electric-cargoaircraft/?mc_cid=2a1e293076.https://www.aircargoweek.co $\mathrm{m} /$ more-join-afklmp-saf/?mc_cid=14644288a9.

[251] Turner, Y. (2021e). SAMAD starts to certify electric cargo aircraft. Retrieved from https://www.aircargoweek.com/samad-starts-to-certifyelectric-cargo-aircraft/?mc_cid=2a1e293076.

[252] Turner, Y. (2021f). TIACA on sustainability: People, planet, prosperity. Retrieved from https://www.aircargoweek.com/tiaca-onsustainability/?mc_cid=d8deab3dfc.

[253] Turner, Y. (2021g). The importance of air cargo to the global economy. Retrieved from https://www.aircargoweek.com/the-importance-of-aircargo-to-the-global-economy/.

[254] TWI Limited. (2021). What is decarbonisation? Retrieved from https://www.twi-global.com/technicalknowledge/faqs/what-is-decarbonisation.

[255] Unique Logistics International. (2021). Unique Logistics International joins Sustainable Air Freight Alliance (SAFA). Retrieved from https://uniquelogistics.com/news/unique-logistics-international-joinssustainable-air-freight-alliance-safa/.

[256] United Nations. (2018). Renewable energy sources cut carbon emissions, efficiently increase electricity output worldwide, delegates say in Second Committee. Retrieved from https://www.un.org/press/en/2018/gaef3501.doc.htm.

[257] United States Energy Information Administration. (2021). Solar explained: Solar energy and the environment. Retrieved from https://www.eia.gov/energyexplained/solar/solar-energyand-the-environment.php.

[258] United States Federal Aviation Administration. (2013). Recycling, reuse, and waste reduction at airports: A synthesis document. Retrieved from https://www.faa.gov/airports/resources/publications/reports /environmental/media/RecyclingSynthesis2013.pdf

[259] Wensveen, J.G. (2016). Air transportation: A management perspective (8th ed.). Abingdon, UK: Routledge.

[260] Wey, C., \& Lee, C.M. (2017). Aircraft emissions: Gaseous and particulate. In E.S. Nelson \& D.R. Reddy (Eds.), Green aviation: Reduction of environmental impact through aircraft technology and alternative fuels (p. 48). Leiden, The Netherlands: CRC Press/Balkema.

[261] Wiedemann, T.\& Minx, J. (2007). A definition of 'carbon footprint'. In C.C. Pertsova (Ed.), Ecological economics research trends (pp. 1-11). New York, NY: Nova Science Publishers.

[262] Williams, I., Kemp, S., Coello, J., Turner, D.A., \& Wright, L.A. (2012). A beginner's guide to carbon footprinting. Carbon Management, 3(1), 55-67. https://doi.org/10.4155/cmt.11.80

[263] Wolfsteller, P. (2021). FedEx invests \$2bn in sustainable technologies. https://www.aircargonews.net/airlines/fedex-invests-2bnin-sustainable-technologies/.

[264] Xu, W., Li, Q., \& Huang, M. (2015). Design and analysis of liquid hydrogen storage tank for high-altitude longendurance remotely-operated aircraft. International Journal of Hydrogen Energy, 40(46), 16578-16586. https://doi.org/10.1016/j.ijhydene.2015.09.028

[265] Yadhav, D., \& Wang, J. (2017). Modelling carbon dioxide emissions from agricultural soils in Canada. Environmental Pollution, 230, 1040-1049. https://doi.org/10.1016/j.envpol.2017.07.066

[266] Ydersbond, I.M., Kristensen, N.B., \& Thune-Larsen, H. (2020). Nordic sustainable aviation. Oslo, Norway: Nordic Energy Research.

[267] Yerel Kandemir S., \& Yayli, M. Ö. (2016). Investigation of renewable energy sources for airports. In T. Hikmet, M. Baris Ozerdem, C.O. Colpan, O. Altuntas, E. Acikkalp (Eds.), Sustainable aviation: Energy and environmental issues (pp. 11-16). Cham, Switzerland: Springer International Publishing.

[268] Yim, S.H.L., Stettler, M. E.J., \& Barrett, S.R.H. (2013). Air quality and public health impacts of UK airports. Part II: Impacts and policy assessment. Atmospheric Environment, 67 , 184-192. https://doi.org/10.1016/j.atmosenv.2012.10.017

[269] Yin, R.K. (2018). Case study research and applications (6th ed.). Thousand Oaks, CA: SAGE Publications.

[270] Zhang, J., Zhang, S., Wu, R., Duan. M., Zhang, D., Wu, Y., \& Hao, J. (2021). The new CORSIA baseline has limited motivation to promote the green recovery of global aviation. Environmental Pollution, 289, 117833. https://doi.org/10.1016/j.envpol.2021.117833

[271] Zhang, Z., Pan, S.Y., Li, H., Cai, J., Ghani Olabi, A., Anthony, E.J., \& Manovic, V. (2020). Recent advances in carbon dioxide utilization. Renewable and Sustainable Energy Reviews, 109799. https://doi.org/10.1016/j.rser.2020.109799

[272] Zhu, D., Asnani, P.U., Zurbrugg, C., Anapolsky, S., \& Mani, S. (2008). Improving municipal solid waste management in India: A sourcebook for policy makers and practitioners. Washington, DC: The World Bank.

[273] Zou, B., Kwan, I., Hansen, M., Rutherford, D., \& Kafle, N. (2016). Airline fuel efficiency: assessment methodologies and applications in the U.S. domestic airline industry. In J.D. Bitzan., J. Peoples \& W.W. Wilson (Eds.), Airline efficiency (pp. 317-352). Bingley, UK: Emerald Group Publishing. 